\title{
38. A REVISED SEISMIC STRATIGRAPHY OF THE TYRRHENIAN SEA: IMPLICATIONS FOR THE BASIN EVOLUTION1
}

\author{
Jean Mascle ${ }^{2}$ and Jean-Pierre Rehault ${ }^{2}$
}

\begin{abstract}
We present and discuss a revision of the Tyrrhenian Sea seismic stratigraphy based on calibration of recent MCS lines thanks to ODP Leg 107 drilling results. Our results indicate that the whole area has been subjected to a succession of short-lived rifting episodes (may be starting before upper Tortonian times) shifting through time toward the east and leading to the creation of discrete oceanic sub-basins. Integration of drilling and seismic reflection data tend to support that the Tyrrhenian Sea passive type margins result from an asymmetric evolution. In this hypothesis, preexisting crustal lineaments (such as former suture zones) and tectonic events in the bordering southeastern collision subduction zone may have facilitated the development of successive eastward dipping normal slip detachment faults.
\end{abstract}

\section{INTRODUCTION}

In the Mediterranean the Tyrrhenian Sea (Fig. 1) developed both behind a subduction-volcanic arc system (the Calabria-Sicily arc) and inside successive collision zones (see Réhault et al., 1987b, and Sartori et al., 1987, for discussion). Both subduction and collision processes are still active east and south of the basin, and result in complex morphologies and structures. The present-day basin includes:

1. A so-called central abyssal plain (with an average of 3400 $3600 \mathrm{~m}$ of water depth), divided into three sub-basins, respectively from northwest to southeast, the Magnaghi, Vavilov, and Marsili Basins (Fig. 1); geophysical evidence (Réhault et al., 1987b), and drilling results (Dietrich et al., 1978; Barberi et al., 1978; Kastens, Mascle, et al., 1987) indicate that the central plain is underlain by an oceanic type crust.

2. Surrounding continental margins intensively cut by distensive fractures; the resulting structural framework includes several disconnected slope basins filled by variable thickness of mostly terrigenous sediments.

Moreover, as demonstrated by the recent ODP 107 drilling cruise (Kastens, Mascle, et al., 1987), the Tyrrhenian Sea results from a short but complex rifting evolution occurring between upper Tortonian and early Pliocene times, i.e., mostly during the latest Miocene.

For almost 20 years, a dense grid of seismic reflection surveys has allowed scientists to propose several seismic stratigraphic interpretations for the whole basin. Successively Morelli (1970), Finetti and Morelli (1973), Fabbri and Curzi (1979), Malinverno et al. (1981), Moussat (1983), Réhault et al. (1987a, b) proposed stratigraphic and/or facies interpretations of single and multichannel seismic data across the Tyrrhenian basin.

In this paper, we intend (1) to briefly review the different seismic interpretations and their consequences concerning the inferred basin evolution, (2) to propose a more reliable seismic stratigraphy of the Sardinia margin and central basin based on calibrations between the recent ODP Leg 107 results and multichannel seismic lines recorded during the site-survey cruise, and

\footnotetext{
${ }^{1}$ Kastens, K. A., Mascle, J., et al., 1990. Proc. ODP, Sci. Results, 107: College Station, TX (Ocean Drilling Program).

2 Laboratoire de Geodynamique Sous-Marine, B.P.48, 06230 Villefranche sur Mer, France.
}

(3) finally to evaluate the consequences of these new interpretations for the inferred evolution of the Tyrrhenian Sea.

\section{OVERVIEW OF THE SEISMIC STRATIGRAPHY BEFORE ODP LEG 107}

As indicated above, scientists working not only on the Tyrrhenian Sea but also on the whole Mediterranean Sea, have been facing three major difficulties concerning the seismic reflection data: (1) the active tectonic and subsequent deformation of the sedimentary cover, (2) the proximity and diversity of sediment sources, and finally (3) the widespread occurrence and variability of the Messinian deposits. The Messinian facies are highly diversified and depend on the interactions between the structural evolution and the Messinian desiccation event. These effects combine to obscure the basin seismic stratigraphy and result in highly variable seismic response. Therefore, it is very difficult to consider interpretations valid for the whole Tyrrhenian domain.

We will first present the continental margin (with a special attention on the Sardinia margin) and then the results from the central abyssal, sub-basin by sub-basin.

\section{The Continental Margins}

\section{The Sardinia-Corsica Margin}

The Sardinia margin and its northern extension, the Corsica margin include three major domains (see Réhault et al., 1987b), from west to east:

1. The upper slope which contains two large and north-south elongated basins, known as the Sardinia and Corsica basins. Those basins are bounded eastward by sublinear, also northsouth trending, basement highs (such as the Pianosa-Elba ridge or the Monte Baronie Ridge) (see Rehault et al., 1987b, for location).

2. The middle slope, which corresponds to a very flat domain extending to $2500 \mathrm{~m}$ of water depth, and known as the Cornaglia Terrace. This area is suddenly interrupted toward the east by a series of north-northeast-trending scarps, the Central Fault system (or R. Selli lineament).

3. The lower margin, extends between $3200-3400 \mathrm{~m}$ and develops mainly off Sardinia. This area is cut by north-northeasttrending small depressions and bordering sublinear asymmetric highs. 


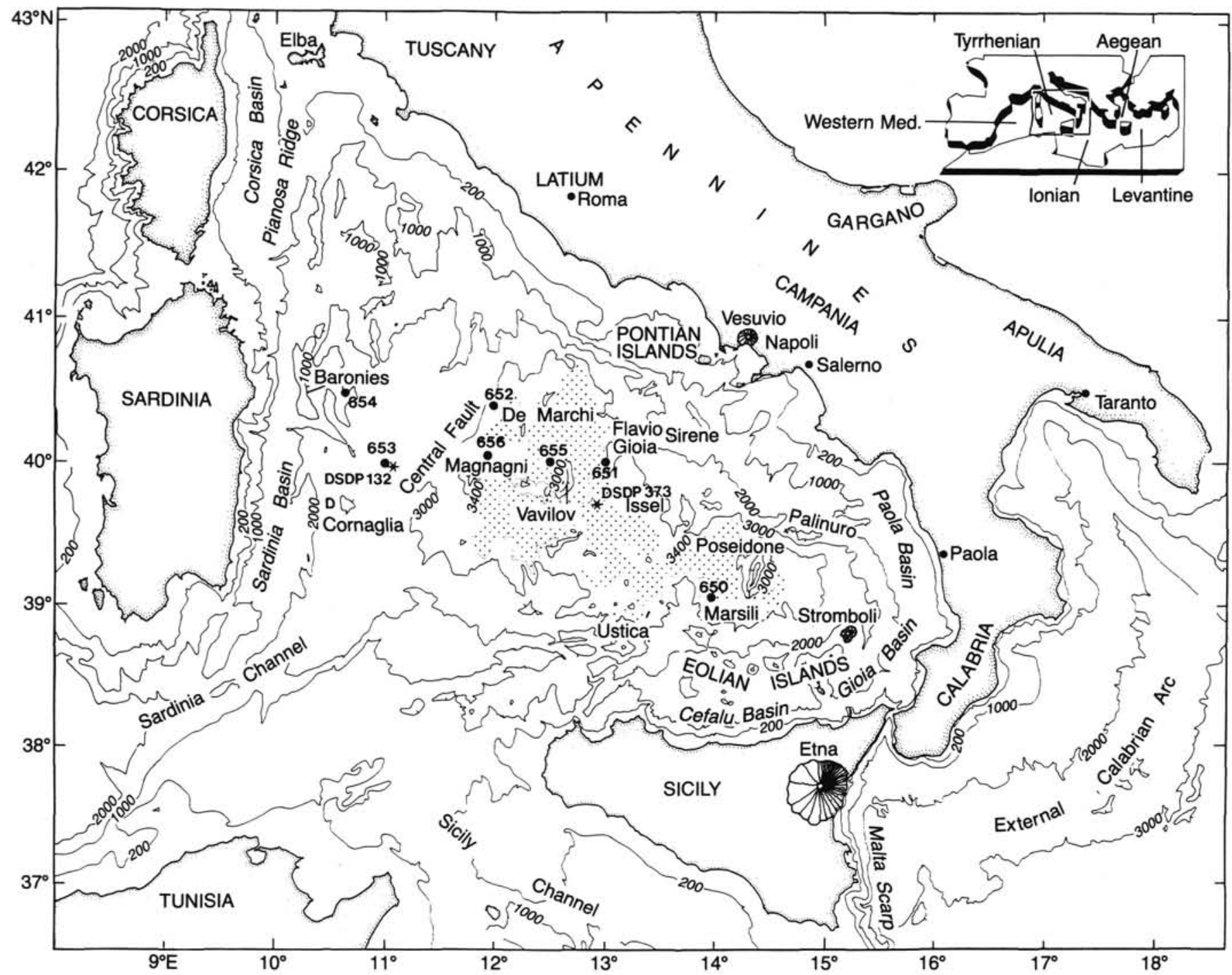

Figure 1 . Simplified bathymetry of the Tyrrhenian area $(200,1000,2000,3000 \mathrm{~m}$ bathymetric lines). The deep central basin (dotted) is enclosed by the 3400 -m isobath. DSDP Sites 132 and 373 and ODP Leg 107 sites locations are indicated.

Each domain shows a different seismic stratigraphy which was worked out by Fabbri and Curzi (1979), Malinverno et al. (1981), Moussat (1983), and more recently by Réhault et al. (1987b, c) (see their Fig. 1).

\section{The Upper Sardinia Basin and Bordering Eastern Domain}

In this area Fabbri and Curzi (1979) (see their plate VII), Curzi et al. (1980), and Moussat (1983) have distinguished the following succession, from top to bottom: (1) a series of welllayered seismic reflectors filling the Sardinia basin with variable thickness (up to $1 \mathrm{~s}$ ) and interpreted as Pliocene-Pleistocene turbidites. The sequence covers either directly a diffractive seismic surface or an intermediate acoustic unit, (2) also characterized by a strongly reflective upper surface interpreted as a late Miocene ("Messinian") erosional surface or as the top of terrigenous deposits (deltaic type), also of Messinian age. A lower seismic unit (3) comprises conformable and well-layered reflectors. Finally, the deepest detected seismic sequence (4) corresponds to an acoustic basement or strongly deformed sedimentary strata. Units 3 and 4 were inferred to be respectively of Tortonian and Oligocene-Miocene age (Fabbri and Nanni, 1980; Réhault et al., 1987c). The bordering eastern domain contains a series of small- scale basement ridges and basins. On several basin-ridge systems a tilting history has been inferred using the geometry of the seismic units (Réhault et al., 1987a). Deep subparallel reflectors dipping to the west are inferred to represent pre-rift sediments of unknown age; an overlying westward dipping wedge of sediments where the dip decreases upsection (estimated to be of middle to late Miocene age) is considered syn-rift; finally a surficial unit of subhorizontal reflectors, inferred to be PliocenePleistocene, is interpreted as post-rift. According to Fabbri et al. (1981), Moussat (1983), and Moussat et al. (1986) an upper Tortonian rifting phase created most of the asymmetric grabens and tilted blocks in the upper margin; on the other hand, Malinverno et al. (1981) suggest a Serravalian-early Tortonian age for most of the margin creation.

\section{The Cornaglia Terrace (middle margin) and the Central Fault} Area

In this region, DSDP Site 132 previously documented a nearlycomplete hemipelagic Pliocene-Pleistocene section, about $200 \mathrm{~m}$ thick (Ryan, Hsü, et al., 1973). The Miocene/Pliocene boundary is marked on the seismic lines by a strong acoustic reflector (the M-reflector of Ryan, 1973, and the Y-reflector of Selli and 
Fabbri, 1971), which indicates the top of Messinian evaporites (Ryan, Hsü, et al., 1973). Thickness in excess of $800 \mathrm{~m}$ of Messinian evaporites have been inferred in this area (Fig. 2), where Curzi et al., (1980) also noted the presence of numerous diapiric structures; the Cornaglia Terrace corresponds in fact to a thick sedimentary basin which is one of the few Tyrrhenian areas where the complete Messinian evaporite seismic sequence (including the halite-bearing diapir-forming "lower evaporite unit") appears well developed (Curzi et al., 1980). Along the Central Fault, piston cores and dredge stations provide evidence of a stratigraphic succession including late Miocene to Pleistocene sediments together with limestones and metamorphic rocks fragments interpreted as probable outcrops of the Sardinia crystalline basement (Colantoni et al., 1981).

\section{The Lower Margin}

East of the Central Fault system, the lower Sardinia margin is also cut in a series of half-graben and tilted blocks. Several of these features are clearly underlain by dipping and wedging seismic units interpreted as indications of fault-bounded blocks tilting (Moussat et al., 1986; Rehault et al., 1987a) (Fig. 3) the superficial, flat-lying cover being made of Pliocene-Pleistocene turbidites. On seismic grounds there is no evidence of typical Messinian evaporitic acoustic facies and therefore, the sequences detected below the " $\mathrm{M}$ " reflector were attributed to pre-Messinian (Tortonian to Oligocene-Miocene) strata submitted to erosion during Messinian times (Moussat et al., 1986; Réhault et al., 1987a). This was considered as evidence that during late Mi-
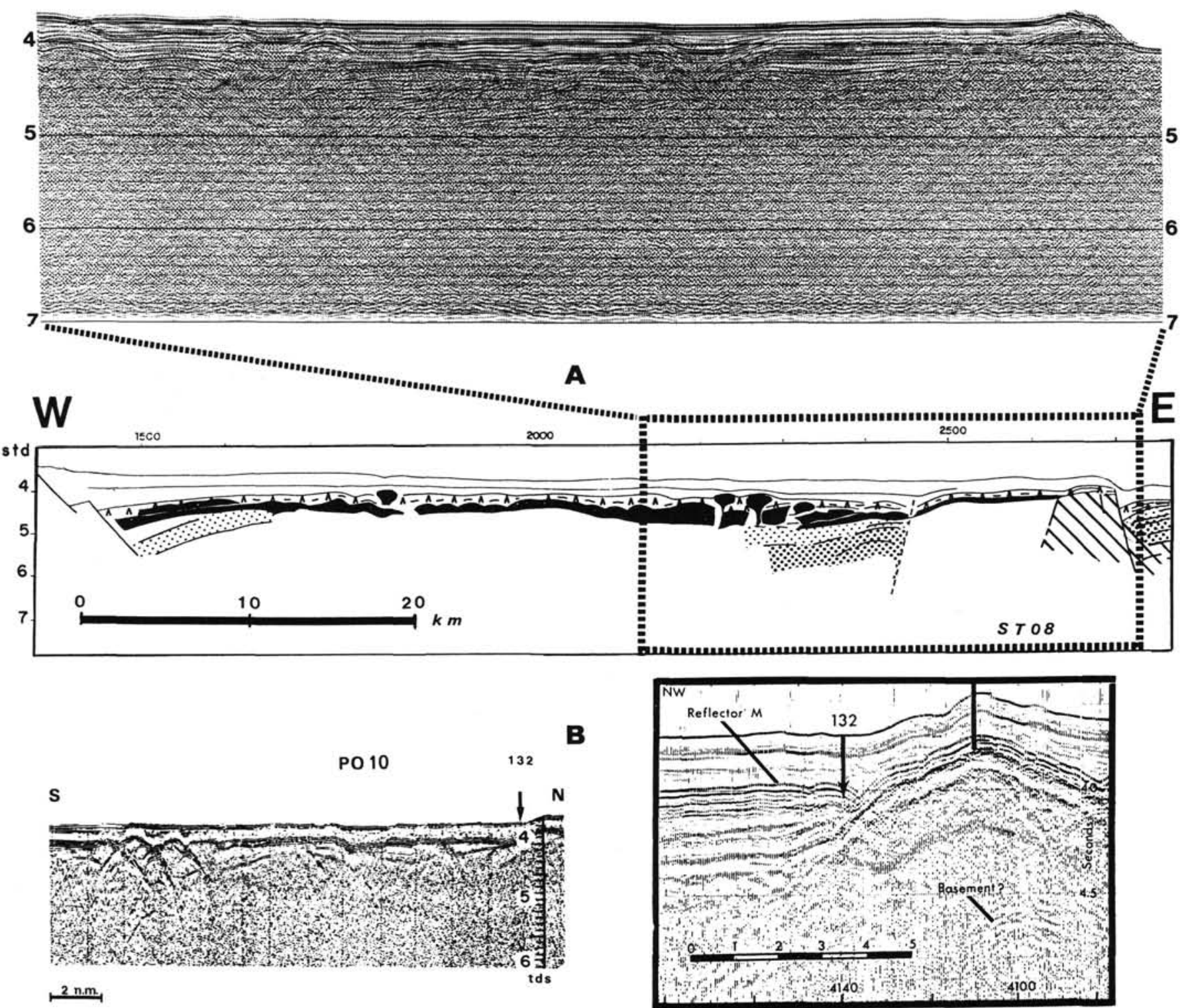

B

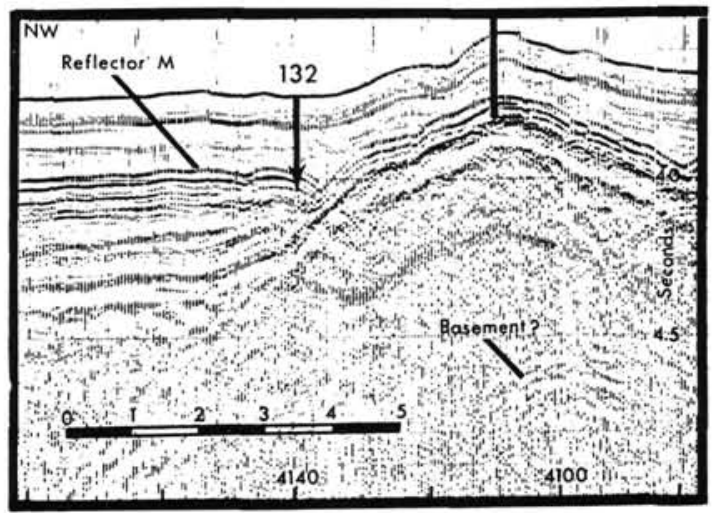

Figure 2. A. Tracing of a MCS line across the Cornaglia Terrace in the vicinity of Site ODP 653 showing the widespread occurrence of Messinian formations covered by thin hemipelagic Plio-Quaternary sediments (in white). The massive halite-bearing diapir forming the middle Messinian section (in black), is overlain by the "upper evaporites." Fine and coarse dots = upper Miocene (Tortonian and older?) sediments. Diagonal lines = inferred continental basement. B. Section of Sparker and MCS seismic lines across Site DSDP 132 (after Fabbri and Curzi, 1979; Ryan, Hsü, et al., 1973). The seismic character of the evaporitic sequence is particularly well expressed. Note particularly the basal unconformity, the massive salt-bearing layer generating diapirlike structures, and the overlying thinly bedded gypsiferous upper evaporites. 


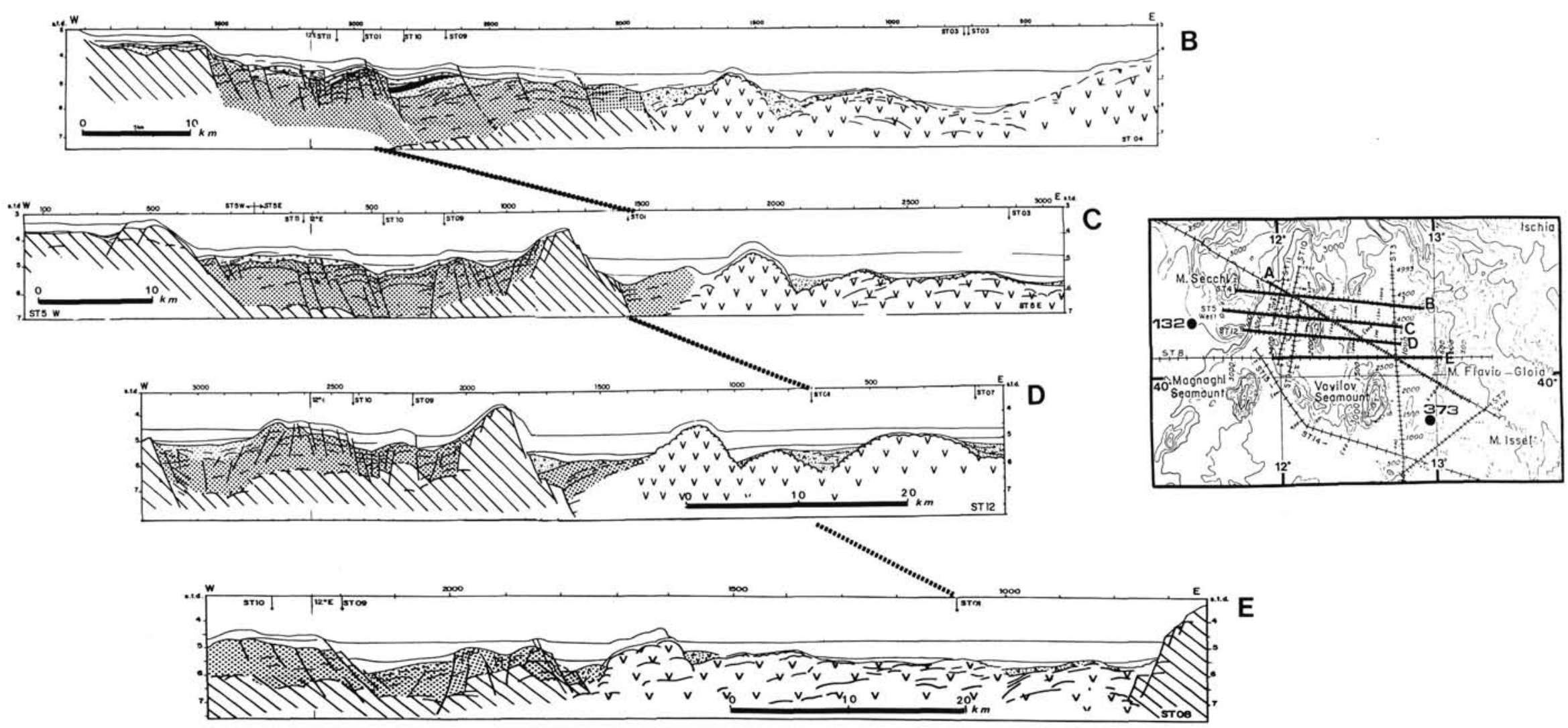

Figure 3. A series of tracings based on MCS lines across the lower Sardinian margin and bordering Vavilov Basin. Same symbols as on Figure 2A; an atypical "Messinian" seismic facies has been observed (stars); VV = magmatic basements and overlying volcaniclastics. Note the intense fracturing of this area of the Sardinia margin. The dashed line connecting profiles indicates the inter-
section with MCS line STOl. 
ocene time the area was in a higher position than the Cornaglia Terrace.

\section{The Eastern and Southern Tyrrhenian Margins}

\section{The Apenninic and Campania Margins}

Like the Sardinian margin, the Apenninic margins are similarly bounded by asymmetric basement highs where pre-Miocene sedimentary rocks have been sampled during submersible dives or by dredging (Dal Piaz et al., 1983; Gennesseaux et al., 1986). The comparable water depth $(2500 \mathrm{~m})$, the presence of underlying sedimentary basins, and the inferred occurrence of Messinian evaporites (Fabbri and Curzi, 1979) have suggested an analogy with the conjugate Sardinia margin, particularly with the Cornaglia Terrace (Réhault et al., 1987a).

\section{The Calabria and Sicily Margins}

Off western Calabria, the margin contains thickly sedimented basins (Paola, Gioia basins) including a thick pile of ponded sediments (up to $5 \mathrm{~km}$ ) inferred to consist of Pleistocene-Pliocene turbidites (Barone et al., 1982). This clastic sequence, characterized by several unconformities, was interpreted to rest on inferred uppermost Miocene deposits but lacking the characteristic signature of evaporites. Comparable slope basins are found along the upper Sicily margin (e.g., the Cefalu Basin and western part of Gioia Basin). These basins seem to have resulted from a similar distensive evolution including very recent events; a typical Messinian "evaporitic" sequence was detected in restricted depressions such as the western Cefalu Basin area and chaotic seismic intervals within the overlying ponded sediments were interpreted as slumps including probable volcanogenic material derived from the Eolian Islands (Fabbri et al., 1981).

\section{The Central Deep Basin}

The central plain can be divided into two sub-basins separated by shallow sills. A northwestern basin, the MagnaghiVavilov Basin, contains two large submarine volcanos (Fig. 1); the Magnaghi volcano is located at the base of the Sardinia margin about $20 \mathrm{~km}$ east of the Central Fault, the Vavilov volcano, (reaching a depth of $684 \mathrm{~m}$ ) bisects the Vavilov sub-basin.

The southeastern sub-basin (Marsili Basin), is roughly rhombohedral in shape and is bisected by the Marsili volcano (culminating at $505 \mathrm{~m}$ below sea level) the largest volcanic structure within the Tyrrhenian Sea.

\section{The Vavilov Sub-Basin}

This deep plain is filled (Fig. 3) locally with as much as 800 $1000 \mathrm{~m}$ of well-layered seismic units interpreted as successions of ponded turbidites, ash layers, and hemipelagic sediments of lower Pliocene through Pleistocene age (Fabbri and Curzi, 1979; Moussat, 1983). Locally a deeper acoustic unit has been detected underlying the well-layered upper unit, and pinching out against acoustic basement highs. This sequence has been tentatively interpreted as indicative of Messinian facies, either "evaporites of marginal zone" (Fabbri and Curzi, 1979), or subaerial volcaniclastics series (Moussat, 1983). Slight angular unconformities have been detected within the turbiditic sequence; they have tentatively been correlated with tectonic events occurring around the Tyrrhenian Sea (Moussat et al., 1986).

Little is known concerning the Magnaghi volcano area, south of $40^{\circ} \mathrm{N}$. There, the bathyal plain corresponds to a deep and smooth area apparently floored by an oceanic type crust according to Duschenes et al. (1986) and where Messinian evaporites have been suspected, at least on seismic grounds (Fabbri and Curzi, 1979; Moussat, 1983).

\section{The Marsili Sub-Basin}

Across the Marsili Basin, seismic lines show numerous interbedded lava flows near the volcano flanks (Réhault et al., 1987b) while, along the western basin rims, dipping reflectors (just covered by a thin layer of subhorizontal sediments), are interpreted as tilted sequences indicating recent extensional events. Within the central basin, a thick series of well-layered reflectors (Figs. $4 \mathrm{~A},-\mathrm{B}$ ) (interpreted as ponded turbidites, ash layers, and hemipelagic sediments) rests directly upon an irregular acoustic basement. On recent MCS lines, a few discontinuous and highly irregular reflectors can be detected within this "acoustic basement" suggesting occurrences of lava flows interbedded within volcaniclastics or marine sediments.

Within the basin infill, Fabbri and Curzi (1979) have distinguished two main seismic sequences, " $A$ " and " $B$ ". " $A$ " was attributed to a sedimentary sequence (middle Pliocene to Recent in age). "B" divided into two subunits, "B1" and "B2", was attributed to sedimentary sequences respectively from early to middle Pliocene and to Messinian thin evaporites. Accordingly Fabbri and Curzi (1979) as well as Malinverno et al. (1981) believed that the entire Pliocene and Pleistocene sequences within the basin rested on thin Messinian units. The dubious Messinian was considered made either of lacustrine or clastic sediments (Malinverno et al., 1981). Moussat (1983) also believed that the Pliocene-Pleistocene section of the Marsili basin was complete but resting on terrain of unknown nature and age (volcaniclastic or volcanic basement).

Within the Tyrrhenian Sea, a dense grid of seismic data has allowed mapping of the Messinian facies (Fabbri and Curzi, 1979; Malinverno et al., 1981; Moussat, 1983), and also of the distribution and thickness of pre-Messinian sedimentary sequences as well as the Pliocene-Pleistocene sediments. The different maps of the presumed pre-Messinian facies distribution (Moussat et al., 1986; Réhault et al., 1987a) clearly indicate the presence of thick deposits on both the Sardinia and Calabria upper margins where two pre-Messinian sedimentary cycles were distinguished (Fabbri et al., 1979; Moussat et al., 1986; Rehault et al., 1987a). In the central basin, pre-Messinian sediments were considered as absent or below the resolution of the seismic records. This suggested that the central basin was not created at that time.

Various maps of the Messinian facies distribution (based on acoustic character) illustrated that, by late Miocene, the middle Sardinia margin was already a subsiding area where thick evaporites were deposited (Fabbri and Curzi, 1979; Malinverno et al., 1981; Moussat, 1983; Rehault et al., 1987a). A so-called "marginal type evaporitic facies," defined by the juxtaposition of thinly laminated strata (Fabbri and Curzi, 1979) was mapped east and west of the central domain and extending on larger areas than pre-Messinian facies. Thin Messinian sequences were mapped as possible volcaniclastic (Moussat, 1983) or subaerial and lacustrine sediments within the Vavilov and Marsili Basins (Malinverno et al., 1981).

In summary, and whatever the inferred geodynamic evolution, thinning of continental crust was believed to initiate in the Tyrrhenian Sea after the western Mediterranean Sea drifting phase, i.e., after $18 \mathrm{Ma}$ ago. According to Malinverno et al. (1981), most of the margins were already created by Serravallian to early Tortonian times, while according to Réhault et al. (1987a) and to Moussat (1983), most of the oceanic crust flooring the central abyssal plain was emplaced in a relatively short period of time, between Messinian and lower Pliocene times.

\section{Seismic Stratigraphy as Deduced From ODP Leg 107 Results}

During Leg ODP 107 (Kastens, Mascle, et al., 1987), three sites were drilled in the central Vavilov and Marsili basins of the 


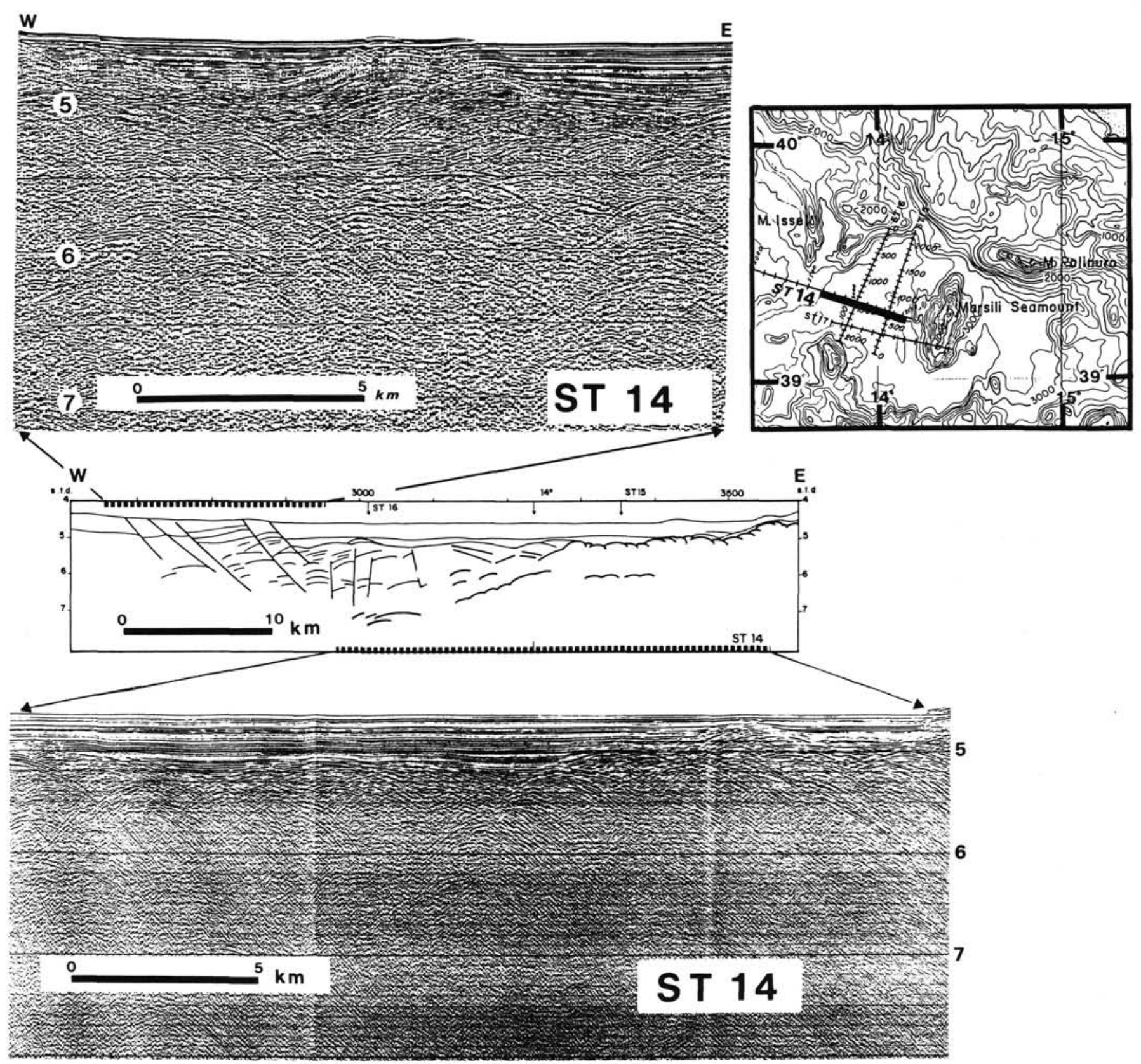

Figure 4. Section and interpretation of a MCS seismic line across the Marsili Basin and its western rim. Note the tilting affecting the recent sediments and highly diffractive and undulating acoustic basement. This seismic character may indicate the presence of interbedded or disrupted lava flow and has previously been interpreted as indicative of probable volcaniclastic material resting on an irregular oceanic type basement.

Tyrrhenian (Sites 650, 651, and 655) and four sites documented the evolution of the Sardinia margin (Sites 652, 653, 654, and 656). All sites were located on multichannel seismic lines (MCS) (Fig. 1) recorded during a previous sites survey cruise. The MCS lines were located in areas already intensively surveyed by single channel seismic reflection profiles; the calibration between this previous grid, the recent MCS lines, and the drilling data provide more reliable seismic stratigraphies for both the Sardinia margin and the Central Tyrrhenian basins; the correlations between the MCS seismic data and the drilled sedimentary section are directly based on interval velocities computed from a 48channel seismic processing at the IFP center. On board the JOIDES Resolution, depths of the major sedimentary discontinuities (lithologies, unconformities, etc.) were predicted using these computed velocities and proved to be very accurate. Addi- tional information such as physical properties and sample velocities measurements are not shown on Figures 6-8 but agree with the proposed correlations (see "Physical Properties" sections in site chapters in Kastens, Mascle, et al., 1987). We are thus confident for the calibration between seismic stratigraphy as shown on MCS lines and stratigraphically dated drilled sections. These results may then be extrapolated with more confidence than in the past to most of the Tyrrhenian domain.

\section{The Sardinia Continental Margin}

Four sites were drilled on the middle and lower parts of the margin; the upper slope, characterized by a series of northsouth-trending basins (the Corsica-Sardinia basin) remains still unexplored by scientific drilling. 


\section{The Middle Slope}

Sites 654 and 653 provided lithologic and stratigraphic data (Fig. 5A) respectively on the base of the Baronie Monte (lines of reliefs bordering the upper slope basin) and on the Cornaglia Terrace.

At Site 654 the MCS lines illustrate (Fig. 5A) the presence of a typical tilted block and bordering half-graben in which we may distinguish four major seismic units that reflect pre-, syn-, and post-rift geometric arrangement (Fig. 6A).

Acoustic unit 1 can be correlated with the 200-m-thick PlioPleistocene post-rift cover of the margin. This sedimentary sequence is made of hemipelagic ooze with subordinate volcaniclastics and sapropelic layers and the section includes near the transition between upper Pliocene and Pleistocene a 2-m-thick basaltic layer well expressed on the seismic records by a discontinuous and diffractive horizon (at about $90 \mathrm{~m}$ below seafloor).

Acoustic unit 2, which consists of a series of closely spaced and well layered reflectors with a constant thickness, corresponds to a sequence of massive gypsum layers (as thick as $7 \mathrm{~m}$ ) interbedded within marls; this represents a typical late Messinian succession onlapping the underlying sequences.

Acoustic unit 3 can be divided into two subunits; the upper unit includes several high-amplitude reflectors, the lower one is almost-as transparent acoustic facies (at least at the drilling location); both subunits thicken considerably toward the west, i.e., toward the half-graben axis (Fig. 5A); the sediments, dated between upper Tortonian and middle to upper Messinian, indicate a synrift evolution at that time.

Unit 4 is topped by high amplitude reflectors gently dipping toward the northwest; the unit has not been documented due to technical problems but the hole bottomed within a conglomerate interbedded in a reddish matrix (between 435 and $465 \mathrm{~m}$ below seafloor). Pebbles from this section consist of Paleozoic Sardinia basement rocks and are likely to be derived from the erosion of the nearby block when progressively tilting.

The main target of Site 653 (nearby former DSDP Site 132) was to recover a complete Plio-Pleistocene pelagic section. The hole (located on the eastern rim of the Cornaglia Terrace) bottomed in the late Messinian sequence which is also made of massive gypsum layers interbedded within marls.

Both sites established the following:

1. On the middle margin, rifting occurred during upper Tortonian times and stopped (or drastically slowed) during upper late Messinian, the late Messinian deposits being almost flat lying, conformable with the Plio-Pleistocene cover;

2. The Messinian desiccation crisis, (known almost everywhere in the Mediterranean) has only been a peculiar sedimentary event interfering with a normal synrift evolution;

3. The upper Tortonian to upper Messinian rifting phase has affected the entire middle Sardinian margin; the Cornaglia Terrace appears effectively underlain by thick evaporites, which indicate that the area was at that time an already relatively deep basin, and

4. Rifting has affected Sardinia alpine and Paleozoic units and their basement.

\section{The Lower Continental Slope}

East of the Cornaglia Terrace, Sites 652 and 656 were drilled on the lowermost slope. This area is cut by linear ridges and basins, also interpreted as rotated blocks and bordering half-grabens. Both sites were drilled few kilometers before the inferred transition with the "oceanic" type crust of the Vavilov deep ba$\sin$.
At Site 652, the MCS line (Figs. 5B and 6B) shows five major seismic units, separated by strong reflectors.

Acoustic unit 1 , about $0.3 \mathrm{~s}$ thick (at site location), correlates with the Pleistocene and Pliocene hemipelagic sequence, but surprisingly includes $20 \mathrm{~m}$ of uppermost Messinian calcareous clay.

Acoustic unit 2 correlates with an alternation of sulfate and carbonate bearing silts, clays, and muds; its top corresponds to the first occurrence of thin gypsum layers while its base can be correlated to a pebble horizon cut by numerous small offset normal faults.

Acoustic units 3 consists of a very monotonous succession of sulfate-rich thin layers, carbonate bearing sand, silt, and clay with a progressive increase downhole of dark gray indurated calcareous siltstones. Westward, this unit changes in seismic response and becomes a lenticular sedimentary body where interval velocity gives a value of $3.4 \mathrm{~km} / \mathrm{s}$; this may indicate the presence of a slightly ductile material (evaporites?) deposited in the axis of the half-graben (Fig. 5).

Acoustic unit 4 is largely made of fine-grained and dark sandstones.

Below this sequence we observe an almost reflection free acoustic unit (Unit 5), characterized by relatively high interval velocities $(3.3 \mathrm{~km} / \mathrm{s})$ and resting upon the acoustic basement $(5.10 \mathrm{~km} / \mathrm{s})$. Unit 5 was too deep to be drilled in the allowed time.

Site 656 (Fig. 5C) was located on the western slope of the last and major tilted block cutting the lowermost margin. On the seismic line we detect beneath a thin cover of ponded sediments a wedging sequence of poorly sorted reflectors resting upon a basementlike reflector. The drilled lower Pleistocene and lower Pliocene sections are characterized by numerous hiatuses and slumps which may indicate sedimentary instabilities and/or tectonic activities. The sediments rest on subaerial clastics including fragments derived from an ophiolitic nappe complex and related cover. In the last $40 \mathrm{~m}$ of the hole only altered fragments of metagabbros were recovered. These gabbros are likely to constitute parts of the De Marchi Monte basement, as also substantiated by observations during scientific dives (Gennesseaux et al., 1986).

Both Sites 652 and 656 on the lower margin indicate that:

1. Rifting occurred in this area during Messinian times and ended in the lower Pliocene times.

2. On the lower margin, the Messinian facies are very different from those recovered on the middle margin. Actually, we believe that the Messinian event was acting either on a subaerial environment (subaerial slope deposits at Site 656), or in a very shallow environment (maybe a lake intermittently invaded by the seawater, Site 652).

3. As for the middle margin, rifting on the lower margin seems to have been a very short event.

4. Rifting has acted on a basement different from that of the middle margin; Site 652 indicates that the lower slope basement, that probably includes an ophiolitic nappe complex and its sedimentary cover, may have been exposed during Messinian and probably before. We can then consider that seismic unit 5 and the acoustic basement detected at Site 652 consist likely of tectonized "alpine" sedimentary formations covering a tectonized alpine basement.

\section{The Deep Central Basins}

Both Vavilov and Marsili sub-basins were drilled during Leg ODP 107; Sites 651 and 655 were drilled just east of the transect drilled on the Sardinia margin (see above), Site 650 lies in the 

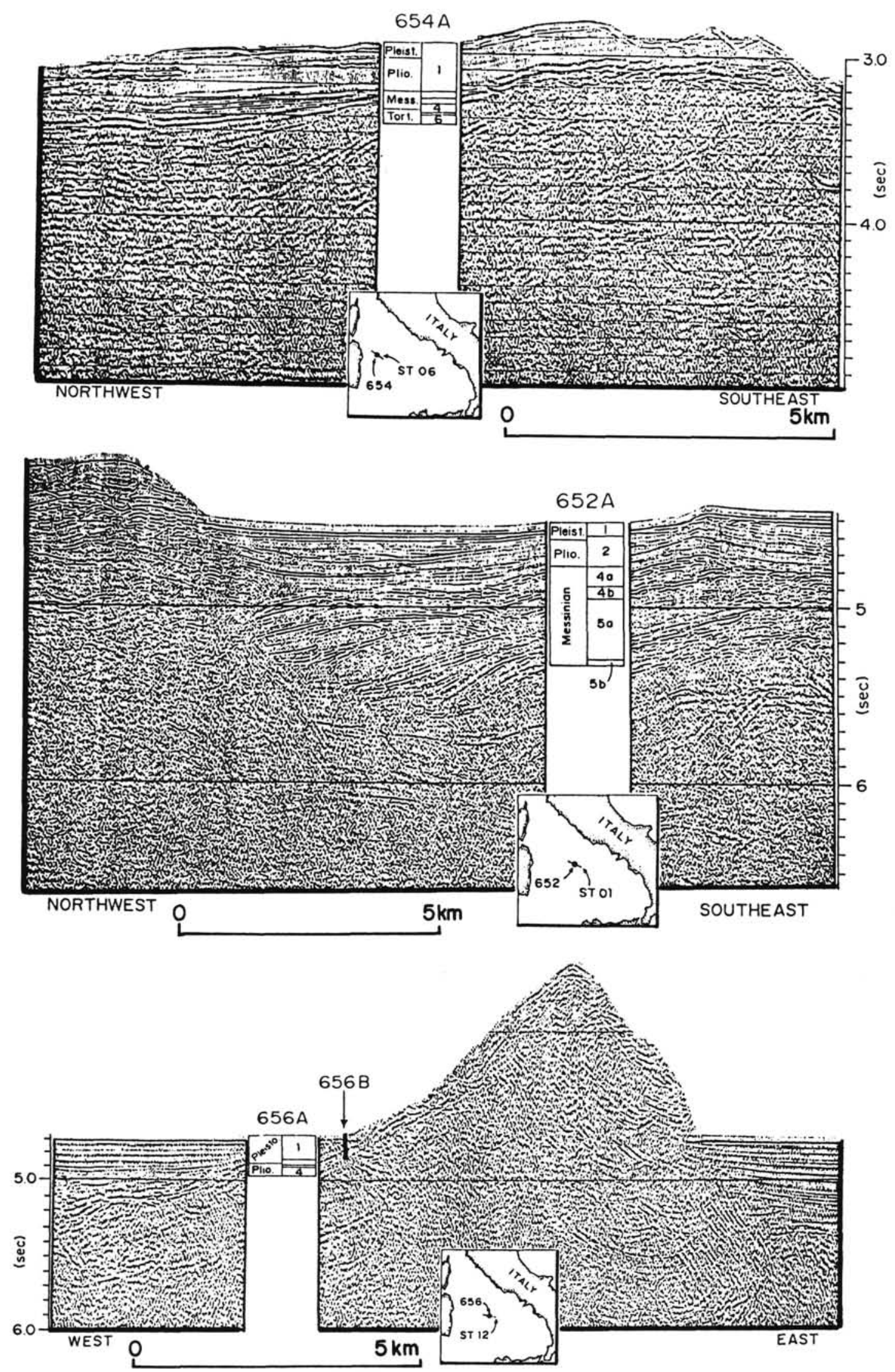

Figure 5. MCS reflection profiles respectively across Sites 654, 652, and 656; simplified core logs inserted into a break in profiles indicate age (left) and lithostratigraphic unit numbers (right). Correlation between cored depth and seismic profiles are based on acoustic velocities measured on cored samples and computed from MCS data processing. Lithostratigraphic units are not the same as seismic units (see Fig. 6). 

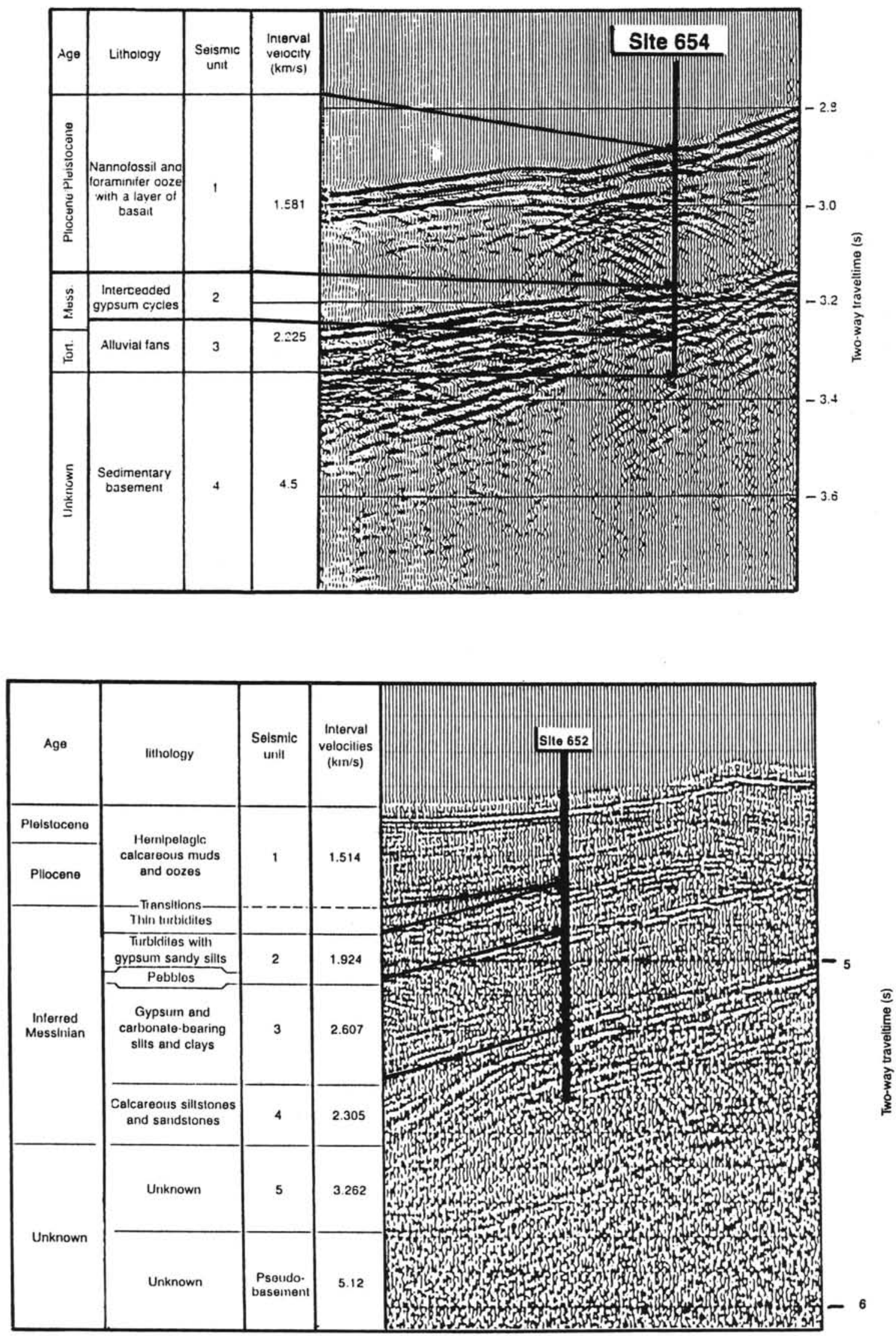

Figure 6. Correlation between reflection seismic lines and respectively age, simplified lithology, interval velocity (as computed from MCS data processing), and seismic units as referred in text for Site 654 (upper) and Site 652 (lower). 
western side of the Marsili basin, about $30 \mathrm{~km}$ west of the volcano.

\section{The Vavilov Sub-Basin}

Site 655 is located on a linear and narrow north-south-trending basement ridge (Gortani ridge) a few kilometers away from the base of the margin (Fig. 7C). Below a thin cover $(80 \mathrm{~m})$ made of lower Quaternary to upper Pliocene nannofossil ooze (including surprisingly a few turbiditic and sapropelic layers), the hole documented almost $120 \mathrm{~m}$ of an acoustic basement made of a series of tholeiitic basalt flows, comparable to the basement previously drilled at DSDP Site 373 on a similarly trending ridge lying just at the base of the Campania margin (Fig. 1).

Located on the eastern flank of a broad basement swell in the center of the basin (Fig. 7), Site 651 was located on a MCS line showing a strong diffractive basement (interval velocities between 3.9 and $4.3 \mathrm{~km} / \mathrm{s}$ ) covered by well layered reflectors. We distinguish three main seismic units (Fig. 8).

Acoustic unit 1 is an almost transparent sequence (about 100 $\mathrm{m}$ thick) including a few strong internal reflectors that correlate with Pleistocene (dominantly volcanogenic) sediments interbedded within marly muds; strong reflectors indicate pumice sandy layers or cemented volcanics breccias.

Characterized by alternating high-low amplitudes reflectors acoustic unit 2 rests in slight unconformity on the underlying one; within the Vavilov basin, this unit thickens considerably and (given an average velocity of $1.7 \mathrm{~km} / \mathrm{s}$ ), reaches a thickness on the order of $500 \mathrm{~m}$. This unit consists of lower Pleistocene to upper Pliocene nannofossil ooze with subordinate volcanogenic turbidites. Unit 3 includes two contrasting acoustic facies; the upper one (3A) is characterized by undulating reflectors, the lower one (3B) by high-amplitude and irregular reflectors; the subunits which pinch out against the acoustic basement high correlate respectively with chalks to colored dolomites and with a succession of lava flows and basaltic breccias. Finally, topped by a strong reflector, the acoustic basement corresponds, (at least at site location), to serpentinized peridotites drilled on 30 m.

Drilling operations within the Vavilov basin demonstrated the following:

1. The basin infilling and basement are much younger than predicted; the oldest dated sediments (about $40 \mathrm{~m}$ above unit 3B) are of upper Pliocene age (2.1 Ma) at Site 651 and of uppermost lower Pliocene (3.2 Ma) at Site 655. K/Ar dating (Feraud, this volume) on basalts of both sites give ages respectively of 4.4 $\pm 0.4 \mathrm{Ma}$ at Site 655 and around $2.6 \mathrm{Ma}$ at Site 651 , ages in good agreement with micropaleontological observations on carbonate cemented interval within the basalts (Kastens, Mascle, et al., 1987).

2. The basin sediments show a marked increase of the volcanogenic component through time from Pliocene to Pleistocene.

3. The Vavilov basin basement is particularly heterogenous; at Site 655 , the basement, (at least in its upper section), consists of typical tholeiitic lava flows; at Site 651, the basement comprises a complex succession where three distinct magmatic episodes can be recognized: (a) an early peridotite emplacement (apparently directly on the seafloor), (b) followed by dolerite intrusions and, (c) a succession of submarine basaltic lava flows.

\section{The Marsili Basin}

Near the western edge of the Marsili basin Site 650 was located on a MCS line where four seismic units are distinguishable (Figs. 4, 7A, 8A).

Acoustic unit 1 (about $0.15 \mathrm{~s}$ thick) corresponds to a very flat, seismically transparent sequence bounded at its base by a strong and continuous reflector; the unit is made of volcanogenic (mostly turbiditic) sediments and its base correlates with a 20-m-thick pumiceous layer.

Acoustic unit 2, made of an alternation of low and high amplitude reflectors with a constant thickness, includes mainly volcaniclastics turbidites of upper Pleistocene age.

Acoustic unit 3 is an acoustically transparent sequence mostly made of homogenous claystone, with subordinate volcaniclastic turbidites,

Acoustic unit 4, which consists of well marked reflectors filling basement lows, correlates with relatively indurated claystones and oozes of lower Pleistocene to uppermost Pliocene age.

Finally, the irregular basement (characterized by a low velocity of $2.7 \mathrm{~km} / \mathrm{s}$ ) correlates with an highly vesicular basalt drilled to $30 \mathrm{~m}$.

As a whole the calibration between the seismic data and the drilling results demonstrate that (1) on the Sardinia Margin the previously inferred pre-Messinian synrift deposits are of uppermost Tortonian to Messinian in age on the upper margin (Site 654) and of Messinian to early Pliocene age on the lower margin (Site 652), and (2) within the Vavilov and Marsili basins respectively the sedimentary infill is not older than middle-upper Pliocene and uppermost Pliocene while it was inferred to be of Messinian and early Pliocene in age.

\section{GEOLOGIC IMPLICATIONS AND CONSEQUENCES}

This new calibration bears direct consequences on both the regional evolution of the Tyrrhenian domain and the geodynamic mechanisms driving this evolution.

\section{Margin and Basin Evolution Timing}

The drilling results and the deduced seismic stratigraphy support the following conclusions:

1. East of the Baronie Seamount, the Sardinia margin results from a rifting evolution characterized by a progressive shift through time from the upper margin toward the central oceanic domain.

Such seaward evolution is well attested by the sedimentary sections drilled on the middle (Sites 653, 654) and lower margins (Site 652). On the western and eastern Cornaglia Terrace rims (middle margin), rotated blocks and accompanying half-grabens were created somewhere between upper Tortonian and upper Messinian times (between 9 and $6 \mathrm{Ma}$ ), while during late Messinian rifting shows a marked decrease and stops around 5 $\mathrm{Ma}$; on the future lower margin (east of the so-called Central Fault system), rifting seems to have occurred mainly during Messinian times (between 6.5 and $5 \mathrm{Ma}$ ) and have ceased during lower Pliocene.

2. MCS lines correlated with Site 650 in the Marsili basin show that post-Messinian sediments are until recent times progressively tilted along the basin rim (Fig. 4A); this observation supports a rifting process moving eastward through time and indicates that a younger rifting event has apparently occurred in connection with the creation of the most recent of the Tyrrhenian Sea deep sub-basins.

3. Rifting in the Tyrrhenian, while characterized by several phases, is a very rapid event. As a whole the middle-lower Sardinia margin has been created in a very short period of time (less than $4 \mathrm{Ma}$ ) when compared to rifting evolution of a more mature passive margin such as the Galicia margin for example (40 Ma; Boillot, Winterer, et al., 1987).

4. A similar migration and apparently sudden evolution is also well demonstrated for the Tyrrhenian oceanic sub-basins; 

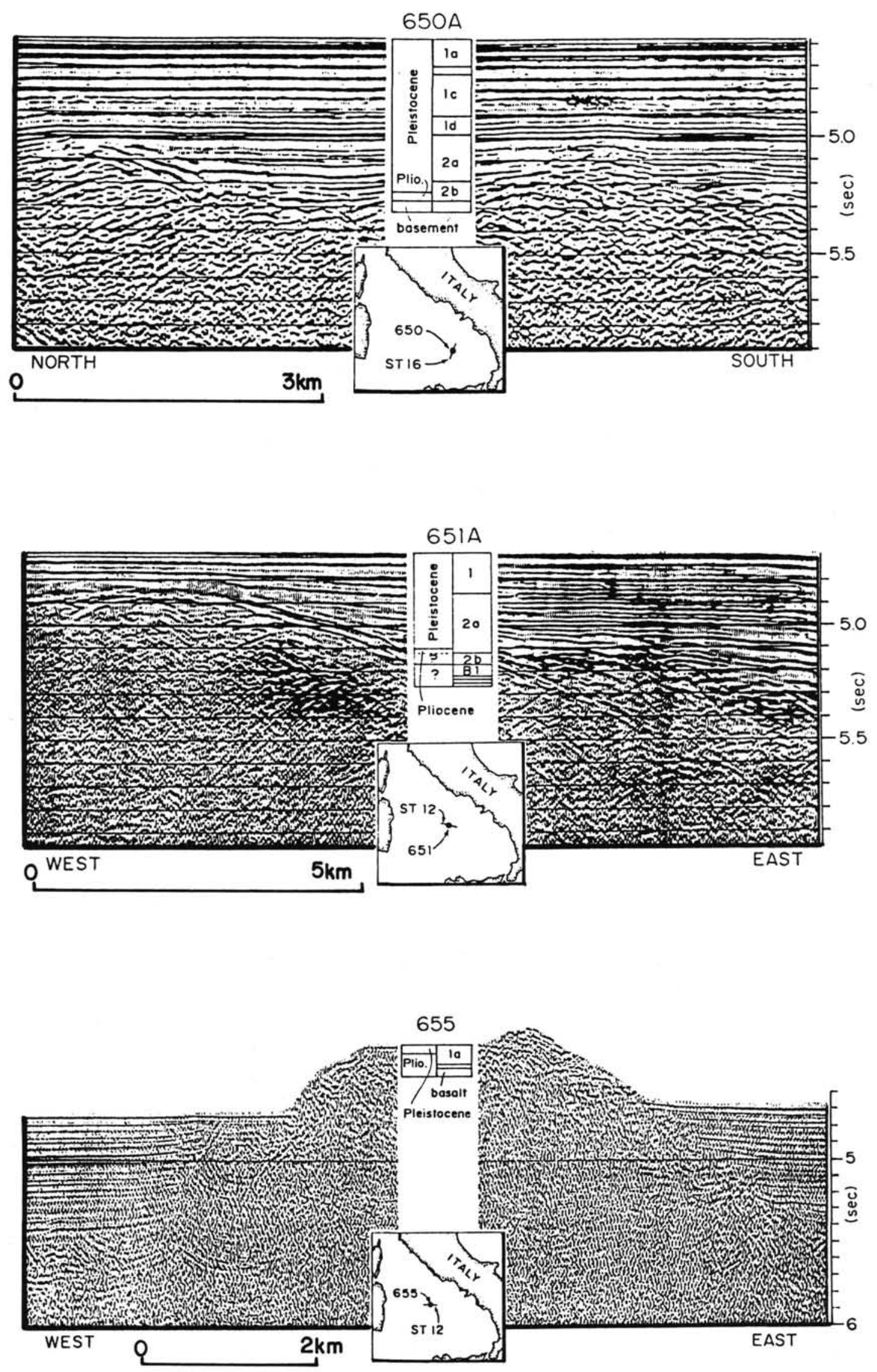

Figure 7. MCS reflection profiles respectively across Sites 650,651 , and 655 . Same explanations as for Figure 5. 

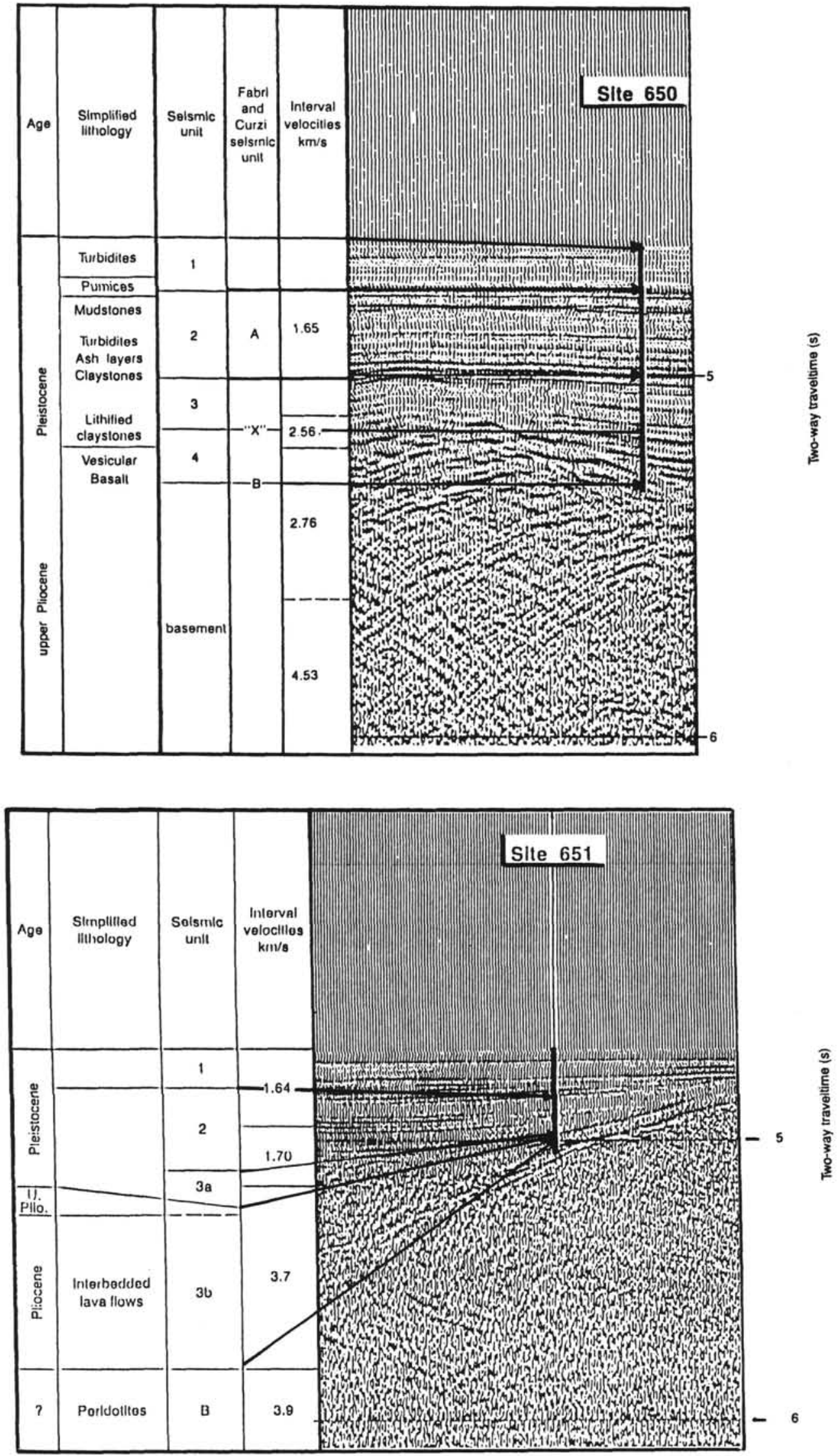

Figure 8. Correlation between reflection seismic lines and, respectively, age, simplified lithology, interval velocity, and seismic units as referred to in text for Sites 650 and 651. 
the Vavilov basin was created in about $3 \mathrm{Ma}$ (somewhere between 5 and $2 \mathrm{Ma}$ ago), by probably two different and successive magmatic episodes (see below); the magmatic basement of the Marsili basin is apparently not older than $2 \mathrm{Ma}$; finally a portion of the Tyrrhenian deep basin (south of Magnaghi seamount and east of Sardinia) may be floored by an upper Miocene oceanic type crust. Supports for this assumption come from the observations in the area of Messinian seismic sequence (Sartori et al., 1987), resting upon an oceanic type crust (Duschenes et al., 1986).

5. Most of the Tyrrhenian back-arc basin has in fact been created in a very short period of time and more recently than previously thought; most of the authors (Malinverno and Ryan, 1986; Rehault et al., 1987a) believed before ODP 107 results that the entire basin was already created around $5 \mathrm{My}$ ago; the Marsili basin is however not older than $2 \mathrm{Ma}$.

\section{Margin and Basin Basements}

1. The continental basement of the Sardinia and other margins surrounding the central basin is particularly heterogenous. Paleozoic Sardinia-type rocks are likely to constitute the basement of the upper to middle Sardinia margin as substantiated by Site 654; the Baronie Monte contains Alpine ophiolitic series as proven by dredging (Colantoni et al., 1981). The lower margin probably rests on tectonized Apennines or Sicilian former units (Site 652) and on Alpine-type series (Site 656) including an ophiolitic nappe complex and parts of its cover; finally, Alpine and Hercynian basements are also known in Calabria. Obviously the upper Miocene rifting events have been active on a very heterogenous continental basement including several former suture zones and related thrusts; such structural heritage should have direct repercussion on the subsequent Neogene structural evolution of the domain.

2. The acoustic basement of both the Vavilov and Marsili basins is also particularly heterogeneous; on seismic grounds (Fig. 9) the basement is characterized most of the time by a rugged and diffractive topography interpreted to be typical of the top of oceanic layer 2. Locally, however (particularly in the vicinity of the basement highs), we observe a rather regular basement, characterized by high interval velocities (between 4.0 and $6.0 \mathrm{~km} / \mathrm{s}$ ); along the swell flanks we also locally notice an irregular basement (with interval velocities between 2.5 and $3.5 \mathrm{~km}$ / s) characterized by weak seismic signal previously interpreted as indicative of interbedded lava flows.

The three drilled sites (Sites 650, 651, 655) have demonstrated the basement heterogeneity. Highly vesicular basalts and/or brecciated pillows lavas drilled in both basins correlate with areas of occurrences of low-velocity, irregular basement; high velocity acoustic basement seems to correspond preferentially either to thick piles of poorly altered lavas flows (Site 655) and/or to serpentinized peridotites (Site 651). Actually, both the seismic data and the drilled sections indicate that high velocity materials are in coincidence with ridges and topographic swells, while low velocity materials are chiefly present in topographic depressions or along swell flanks. Within the Marsili basin, there is no evidence of high velocity basement near the sediments contact, and high-velocity material appears to be covered by a low velocity basement a few hundred meters thick.

\section{Regional Evolution}

The drilling data substantiate that accelerated phases of rifting and of oceanic basin creation fit well with a model of progressive shift through time of the southeastern bordering subduction zone (Kastens, Mascle, et al., 1988); however such an evolution is only supported for the middle to lower Sardinia margin and bordering basins. Since ODP results, we have tenta- tively correlated numerous seismic lines, (including few a MCS), with the drilling data; these correlations tend to indicate that the upper margin and maybe parts of the Cornaglia Terrace (or middle margin) have been apparently affected by distensive events, prior to upper Tortonian times; for example, the eastern border of the Sardinia basin (on the upper margin) (Fig. 10) contains thick sequences (1-2 km) covered in onlap by pre-Messinian and Messinian (including onlapping evaporites) attributed seismic units; the classical Messinian seismic sequence can also be detected along the southern Cornaglia Terrace (Fabbri and Curzi, 1979; Malinverno et al., 1981) covering a wedge of underlying strata indicating the presence of already subsiding basins. All these observations support the assumption that the area may have been affected by distension prior to upper Tortonian may be in Serravallian times (Malinverno et al., 1981; Rehault et al., 1987c) or even before. If such correlations are correct, the late Tortonian-Messinian rifting event documented by drilling on the Sardinia Margin at Site 654 may represent a younger rifting stage superimposed on one or several previous distensive events.

Taking into account such a stepwise and progressive shift of the distension through time, we are inclined to believe that the documented evolution represents only the last phases of a global evolution linked to the general convergence between Africa/ Apulia and Europe leading previously to the creation of the western Mediterranean basin; this basin has been created in a short period of time, (between 30 and $18 \mathrm{My}$ ago; see Rehault et al. 1984, 1985, and references herein for discussion) as the consequence of the subduction of an oceanic realm extending between Europe and Apulia/Africa. The margin formation of the western Mediterranean took place in a very short time (chiefly between 26 and $21 \mathrm{Ma}$ ago; Burrus, 1984, Thomas and Gennesseaux, 1987), a duration similar to the one we documented for the Tyrrhenian Sea. In fact, the end of the western Mediterranean drifting phase (around $18 \mathrm{Ma}$ ago) has been correlated with a major collision occurring between a microcontinent (Corsica-SardiniaCalabria) and the Apulia-African foreland (Biju-Duval, 1984). We accordingly infer that the discrete and shifting episodes of rifting and of oceanic basin creation in the Tyrrhenian Sea have been directly controlled by similar collisions events between Europe and western Apulia (Sartori et al., 1987), as well as Auroux (1987), suggest relationships between rifting and oceanic basin creation timing on one side and timing of the surrounding collision events on the other hand.

\section{CONSEQUENCES ON THE CONTINENTAL MARGINS AND OCEANIC BASINS EVOLUTION}

The timing of tectonic event established by drilling (and extrapolated through calibration of MCS and SC seismic lines) bring new constraints concerning models of evolution of the passive Sardinia margin and of creation of the bordering deep oceanic basins.

\section{Continental Margin Geodynamic Evolution}

It is not surprising that in a back-arc setting (where active constraints due to the bordering subduction interact with normal margin formation), a simple lithospheric stretching model (McKenzie, 1978) is difficult to apply to explain both the structural evolution and the subsidence of a passive margin. However, taking into account the different structural characteristics and the timing, two possibilities that could explain the Sardinia passive margin evolution can be considered:

1. The margin as the result of a stepwise rifting and/or propagating rift evolution (Courtillot, 1982; Vink, 1982),

2. The margin as the result of an asymmetric evolution controlled by low angle crustal shear zones (Wernicke, 1981; 1985; Lister et al., 1986). 

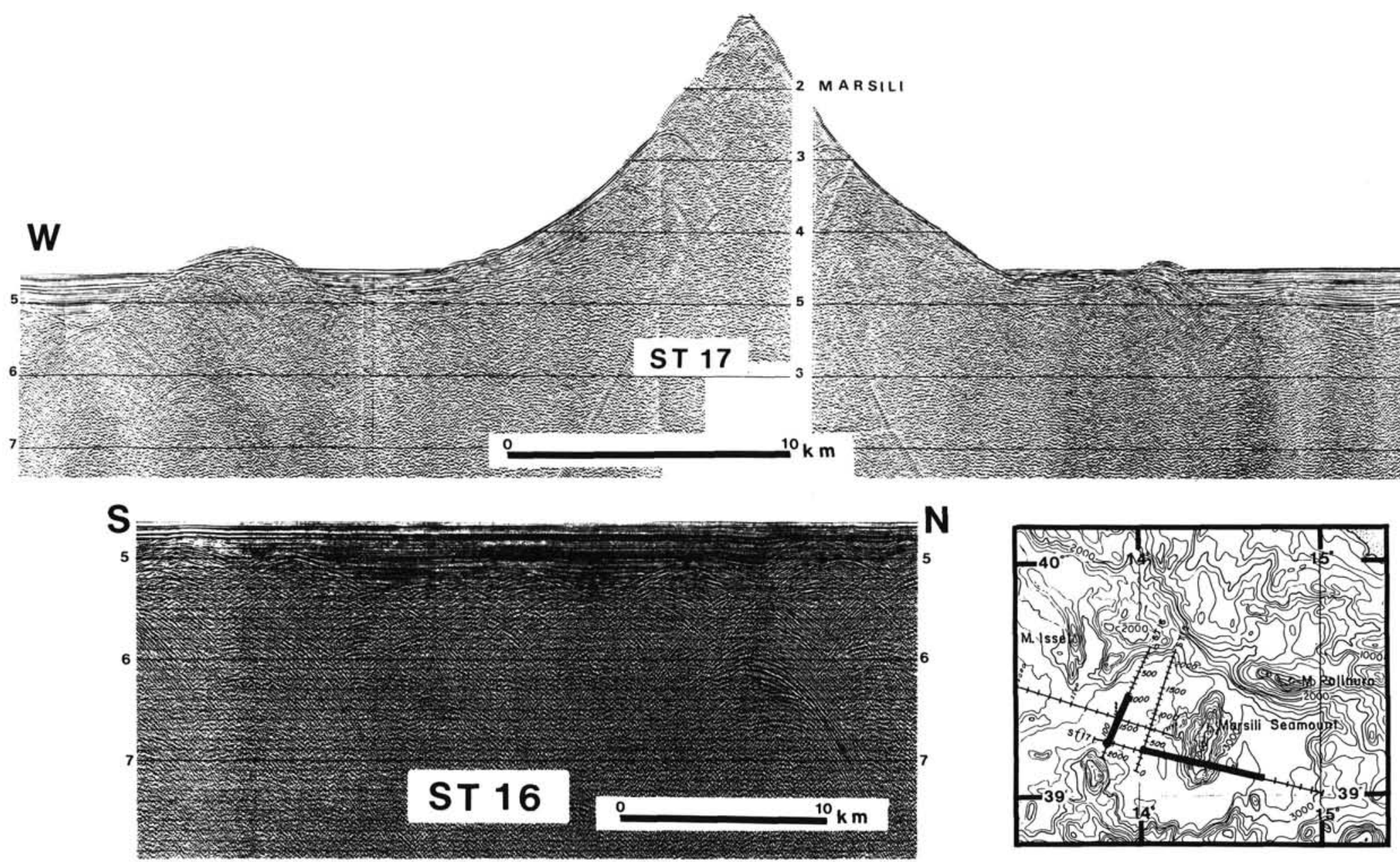

(A)

E 


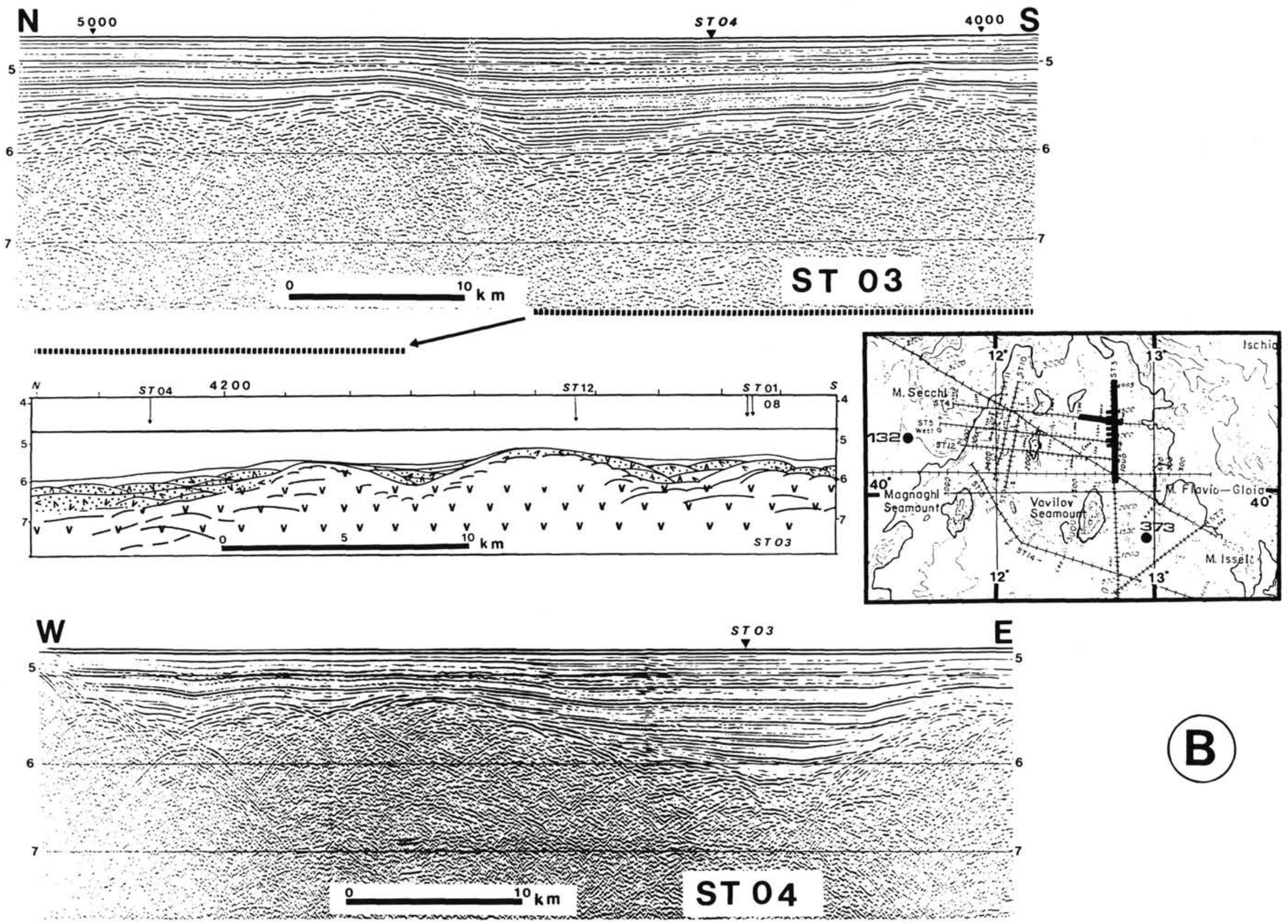



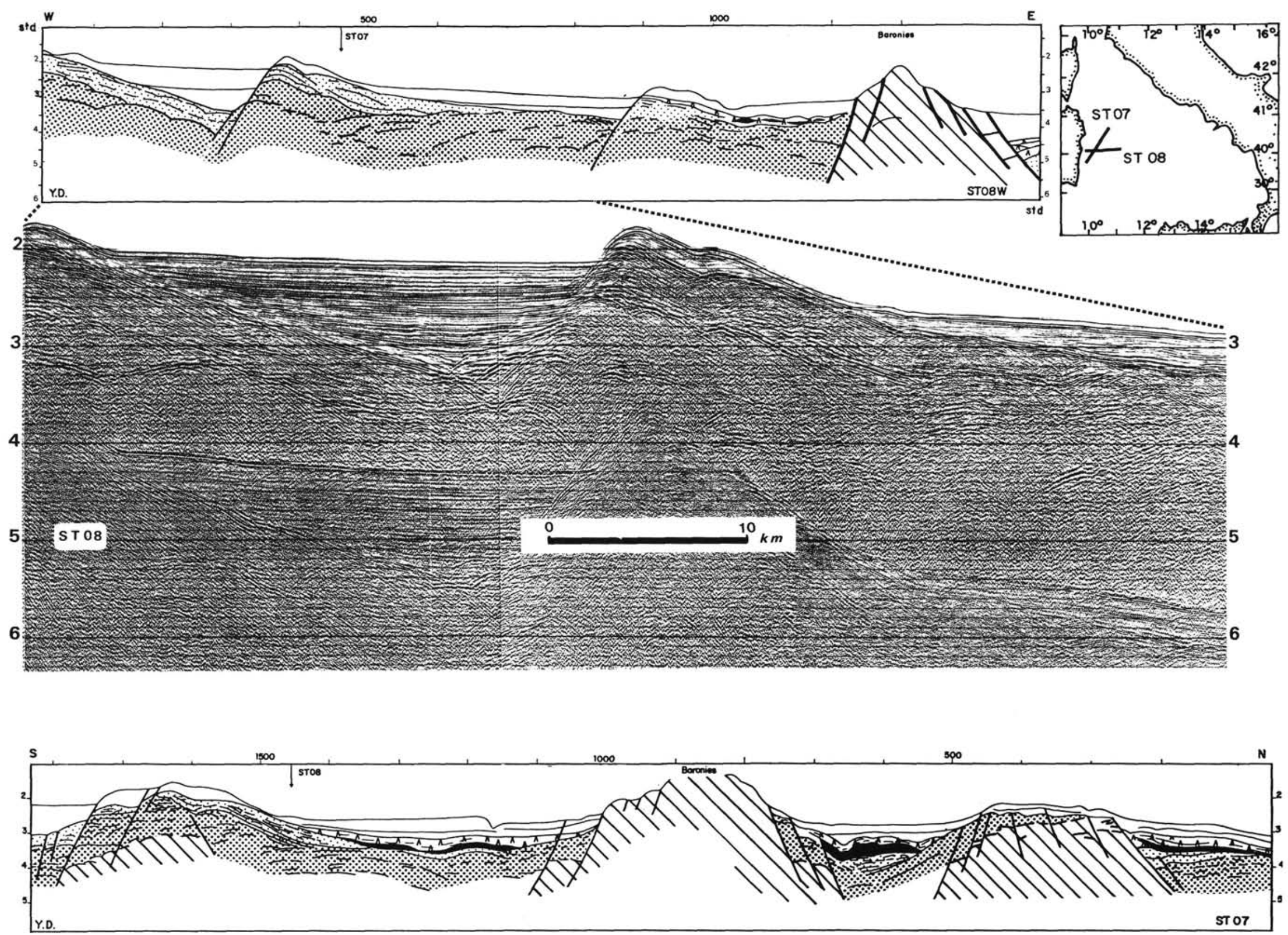

Figure 10. Two tracings and a detail of MCS seismic lines across the Sardinia upper middle margin showing a thick sequence covered in onlap by inferred pre-Messinian and Messinian seismic units indicating a probable distensive evolution prior to upper Tortonian time. Locally, the margin has been reactivated in the landward-verging tilted blocks during and after Messinian time. Same symbols as on Figure 2. 


\section{The Margin as the Result of a Stepwise or Propagating Rifting}

Several observations support the hypothesis of a complex rifting evolution acting not only on the Sardinia margin, but on the Tyrrhenian domain as a whole. For example, drilling data substantiate two distinct episodes of rifting occurring successively in late Tortonian-late Messinian on what is now the middle margin area and in Messinian-early Pliocene on what is now the lower margin area. Moreover seismic data (tentatively calibrated with the drilling results) show that the upper Sardinia margin may have been submitted to a previous extension (Serravallian?, lower Tortonian?). At least, three successive phases of rifting, progressively shifting eastward, are thus suspected. Each rifting event seems to have resulted in the creation of discrete, north-south-trending, thinned continental areas as apparently evidenced by structural mapping (see Rehault et al., 1987a, b). Actually two of these rifts, (slightly widening toward the south), may have given birth to two restricted oceanic basins, the Magnaghi basin along the southeastern Sardinia margin and the Vavilov basin extending at the base of the northeastern Sardinia margin. We also noticed that rifting has also been active until recent times around the Marsili basin as clearly evidenced by the tilting of recent (Pleistocene) strata around the basin borders (Fig. 4A).

We can therefore interpret the entire domain as a progressively thinning area with, several (three or four) distinct periods of rifting, which give rise to restricted, short-lived oceanic basins (Fig. 11).

\section{The Margin Development as the Result of Crustal Shear Zones}

Several arguments are in favor of a margin development controlled by the activity of one or several crustal shear zones as initially proposed by Trincardi and Zittellini (1987) and more recently by Kastens, Mascle, et al. (1988). First, we note a very rapid and apparently jerky evolution of the extension migrating through time. We also notice a difference between a wide ( 250 $\mathrm{km})$ Sardinia passive margin and a relatively narrow $(120 \mathrm{~km})$ peninsular Italy margins. The presence of major structures of regional extent (such as the Baronie Monte or the Central Fault zone potential upper crustal breakaways) bordering wide structural domains as well as the occurrence of typical small size rotated blocks (possible extensional allochthons) along the lower margins can also be considered as good supports for a detachment fault controlled evolution. Moreover, we also should consider that the Sardinia-Calabria margin basement is particularly heterogenous and includes several sutures and associated thrust zones; ophiolitic rocks have been dredged (Baronie Monte) or drilled (De Marchi Monte) and indicate that former nappes complex (may be similar to obducted westward-verging ophiolitic series known in northeast Corsica, Sartori et al., 1987) run within the margin basement. We suspect that these preexisting zones of crustal weakness could be ideal candidates for low-angle detachment faulting if reactivated by posterior extension as it has been the case within the Tyrrhenian domain since the late Miocene. The Tyrrhenian continental crust may then have been subjected

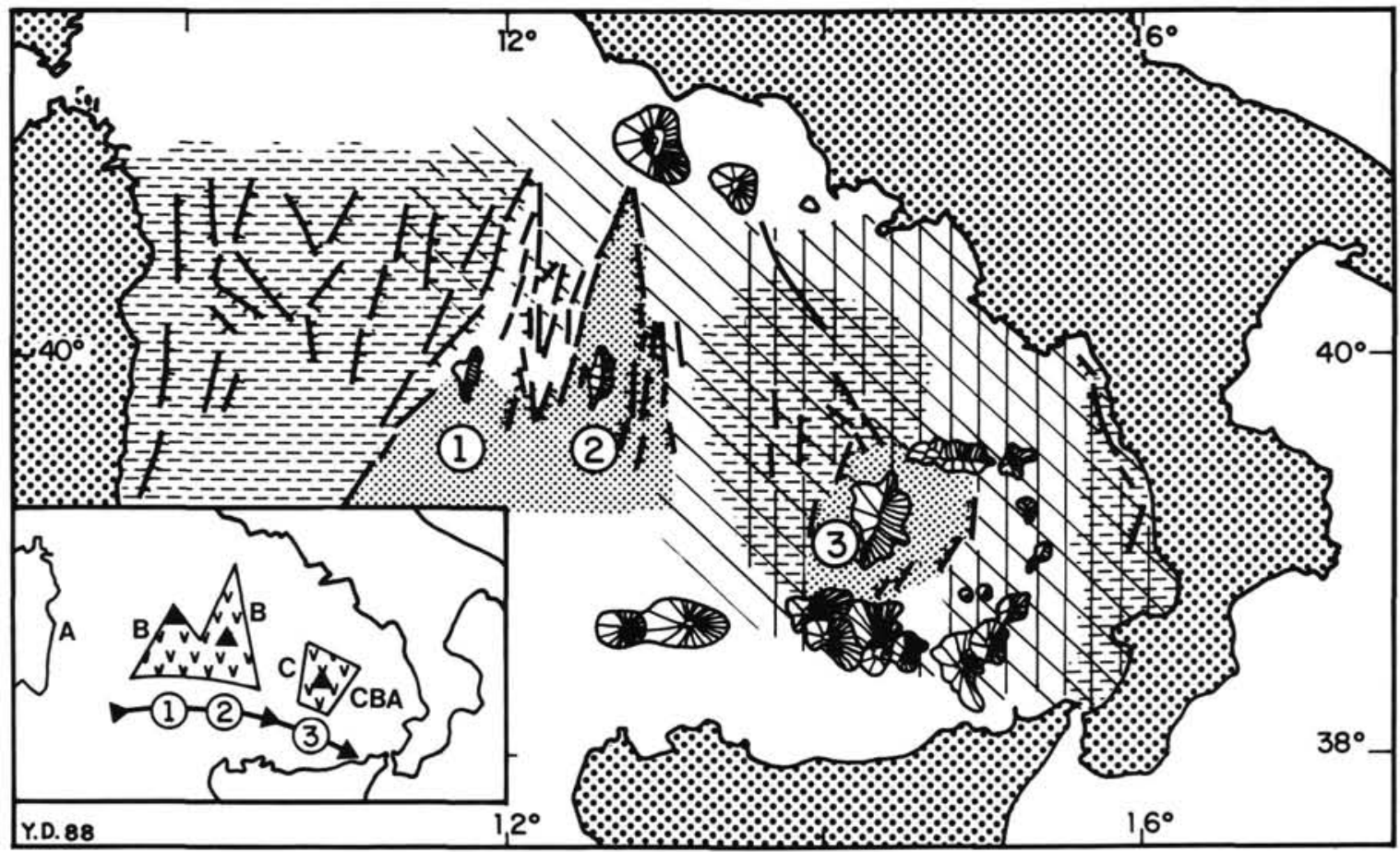

Figure 11. Structural sketch of the central Tyrrhenian (simplified from Rehault et al., 1987a) showing the major structural features of both the margins and deep Tyrrhenian basins. Note the three narrow and triangular-shaped oceanic Magnaghi (1), Vavilov (2), and Marsili (3) sub-basins. Hatched = continental margin areas affected by the first rifting event; diagonal lines = continental margin areas reactivated and submitted to a second rifting event; vertical lines = margin areas reactivated and submitted to a third rifting; dotted = the oceanic crust floored basins. In the insert map, sketch illustrates the successive inferred phases of the margin creation and of the oceanic basins formation within the Tyrrhenian domain (see text for detailed explanation). $\mathrm{A}=$ first identified rifting episode (pre-upper Tortonian); $\mathrm{B}=$ second rifting episode (upper Tortonian-Messinian); $\mathrm{C}=$ third rifting episode Pliocene: $1,2,3$, refers to the different oceanic basins created at the end of each rifting phase. The black arrow shows the eastward migration through time of both margin rifting and oceanic basins creation. Black triangles show the emplacement of major axial volcanoes (Magnaghi, Vavilov, Marsili). 
to a multidetachment faulting according to the model of Lister et al. (1986).

In this framework, the Baronie Monte area (submarine extension of the Alpine Corsica obduction zone), the Central Fault, and possibly the major lower margin asymmetric blocks (De Marchi Monte and equivalent) may be interpreted as superficial scars of three distinct and successively activated, eastward-dipping, detachment faults. The seaward migration through time of the rifting and subsidence will be the consequence of successive locking and upbowing of distinct detachment fault systems; the sudden lowering (early Pliocene) of the Lower Sardinia margin may be a direct consequence of such activity, leading finally to the exposure of upper mantle rocks within the Vavilov Basin as also proposed by Kastens, Mascle, et al. (1988).

If such geodynamic scenario is correct, we may further propose that the rifting and subsequent creation of the Marsili basin and surrounding margins have also been related to a southeastward jump of the detachment fault activity. Being locked toward the east by the collision, the extension would have used another preexisting crustal shear zone (Apenninic thrusts or Alpine suture, known in Calabria).

\section{Oceanic Basin Evolution}

As already indicated, the nature of the magmatic basement in both oceanic sub-basins (Vavilov and Marsili) appears highly variable.

1. In the Vavilov basin oceanic tholeiites were drilled on two north-south-trending and almost symmetrically arranged basement ridges lying respectively along the western (see Sartori, this volume, for discussion on dating) (Site ODP 655) and eastern (Site DSDP 373) borders of the basin. The presence, in such symmetrical setting, of MORB type magma is in favor of some kind of seafloor spreading process, at least during early Pliocene times. However a more unusual basement succession (maybe of late Pliocene age) characterizes the axis of the basin. The drilled geological succession, which contains serpentinized peridotites, dolerites, plagiogranites, and two cycles of brecciated lava flows, is surprisingly similar (except for its age and overlying cover) to Late Jurassic ophiolites succession of the Ligurian realm interpreted as remnants of fault-emplaced ultramafic oceanic floor (Lemoine et al., 1987). We may consider that after a progressive "scalping" of the continental crust, ultramafic rocks have been directly emplaced on the seafloor as a possible consequence of tectonically controlled upper mantle uplift. If correct, the sequence of events will agree with the model of an asymmetric continental extension as previously inferred for the margin development (see above) (Fig. 12).

2. The nature and mechanisms of emplacement of the Marsili basin magmatic basement remain more difficult to ascertain. The low velocity vesicular basalt drilled at Site 650 has apparent calc-alkaline affinities but it overlies a relatively high velocity basement (about $4.5 \mathrm{~km} / \mathrm{s}$ ). As in the case of the Marsili volcano itself, we may believe that the entire basin contains both tholeiitic and calc-alkaline basalts. This would indicate that the basin is floored by an oceanic type crust (as substantiated by geophysical data) progressively contaminated by volcanic arc magmatic series derived from the neighboring Eolian island arc.

3. Both oceanic sub-basins contain large, north-south-trending, volcanoes about $60 \mathrm{~km}$ in length. Absolute ages on samples from respectively the Magnaghi, Vavilov, and Marsili volcanoes vary between 2.3 and $0.2 \mathrm{Ma}$ (Selli, 1977; Colantoni et al., 1981; Robin et al., 1987) indicating very recent activities, much younger than the sub-basins apparent end of creation. As an hypothesis, we propose that since normal horizontal seafloor spreading has successively been locked in each sub-basins (maybe in relation with the progress of the surrounding collision), the magma, originating from the shallow upper mantle, was still delivered but according to an "upbuilding" mechanism.

4. The presence, near the transition between continental and oceanic crusts, of large and elongated volcano (such Vavilov and Marsili) including thick piles of interbedded lavas flows may also be significant when considering the origin of dipping reflectors known along several passive margins (Hinz, 1981; Mutter et al., 1982). In some cases, prior to normal accretionary process, when the upper mantle is already shallow, huge volcanoes may be built near the base of the margin as a consequence of an initiating magmatic differentiation; if "normal" seafloor spreading is taking place, a more typical oceanic crust is created; the sublinear system of volcanoes is then split and starts to subside giving birth to interbedded lava flows along the lower slope, good candidates for potential dipping reflectors.

\section{ACKNOWLEDGMENTS}

We acknowledge competence of the JOIDES Resolution team during the ODP Cruise Leg 107 and the IFP technical team for the MCS program. Discussions with many colleagues from ODP Leg 107 Scientific Party have greatly benefited this work. ASP ODP France has partly supported this research. We gratefully acknowledge K. Kastens, J. Labrecque, and A. Malinverno for helpful review of this paper. This is Contribution no. 468 of the GEMCO UA CNRS 718.

\section{REFERENCES}

Auroux, C., 1987. Essai d'évolution géodynamique du Bassin Tyrrhénien, et de son avant-pays [Ph.D. dissert.]. Univ. de Nice.

Barberi, F., Bizouard, H., Capaldi, G., Ferrara, G., Gasparini, P., Innocenti, F., Joron, J. L., Lambret, B., Treuil, M., and Allegrè, C., 1978. Age and nature of basalts from the Tyrrhenian abyssal plain. In Hsü, K. J., Montadert, L., et al., Init. Repts. DSDP, 42: Washington (U.S. Govt. Printing Office), 509-514.

Barone, A., Fabbri, A., Rossi, S., and Sartori, R., 1982. Geological structure and evolution of the marine areas adjacent to Calabrian arc. Earth Evol. Sci., 3:207-221.

Biju-Duval, B., 1984. Les marges continentales françaises de la Meditérranée. In Les marges continentales actuelles et fossiles autour de la France: Paris (Masson), 251-334.

Boillot, G., Winterer, E. L., Meyer, A. W., et al., 1987. Proc. ODP, Init. Repts., 103: College Station, TX (Ocean Drilling Program).

Burrus, J., 1984. Contribution to the geodynamic synthesis of the Provencal basin (northwestern Mediterranean). Mar. Geol., 55:247-269.

Colantoni, P., Fabbri, A., Gallignani, P., Sartori, R., and Rehault, J. P., 1981. Carta Litologica e Stratigrafica dei mari italiani. Litografica Artistica Cartografica. Firenze.

Courtillot, V., 1982. Propagating rifts and continental break-up. Tectonics, 1:239-250.

Curzi, P., Fabbri, A., and Nanni, T., 1980. The Messinian evaporitic event in the Sardinian basin area (Tyrrhenian Sea). Mar. Geol., 34: 157-170.

Dal Piaz, G. V., Del Moro, A., Sabatino, B., Sartori, R., and Savelli, C., 1983. Geologia del Monte Flavio Gioia (Tirreno centrale). Mem. Sci. Geol., Univ. Padova, 35:429-452.

Dietrich, V., Emmermann, R., Puchlt, H., and Keller, J., 1978. Oceanic basalts from the Tyrrhenian Basin, DSDP Leg 42A, Hole 373A. In Hsü, K. J., Montadert, L., et al., Init. Repts. DSDP, 42: Washington (U.S. Govt. Printing Office), 515-530.

Duschenes J., Sinha, M. C., and Louden, K. E., 1986. A seismic refraction experiment in the Tyrrhenian Sea. Geophys. J. R. Astron. Soc., 85:139-160.

Fabbri, A., and Curzi, P., 1979. The Messinian of the Tyrrhenian Sea: seismic evidence and dynamic implications. G. Geol., 43:215-248.

Fabbri, A., Gallignani, P., and Zitellini, N., 1981. Geologic evolution of the peri-Tyrrhenian sedimentary basins of Mediterranean margins. In Wezel, F. C. (Ed.), Sedimentary Basins of Mediterranean Margins: Bologna (Tecnoprint), 101-126.

Fabbri, A., and Nanni, T., 1980. Seismic reflexion study of the Sardinian Basin (Tyrrhenian Sea). Geol. Mediterr., 7:161-178.

Finetti, I., and Morelli, C., 1973a. Geophysical exploration of the Mediterranean sea. Boll. Geofis. Teor. Appl., 15:263-344.

Gennesseaux, M., Rehault, J. P., Thomas, F., Colantoni, P., Fabbri, A., Lepvrier, C., Mascle, G., Mauffret, A., Polino, R., Robin, C., 
and Vanney, J. R., 1986. Résultats des plongées en submersible Cyana sur les blocs continentaux basculés et le volcan Vavilov (mer Tyrrhénienne centrale). C.R. Acad. Sci. Paris, 2:785-792.

Hinz, K., 1981. An hypothesis on terrestrial catastrophes, wedges of very origin and paleoenvironment significance. Geol. Jahrb., E:328.

Kastens, K., Mascle, J., et al., 1988. ODP Leg 107 in the Tyrrhenian Sea: insights into passive margin and back-arc basin evolution. Geol. Soc. Am. Bull., 100:1140-1156.

Kastens, K. A., Mascle, J., et al., 1987. Proc. ODP, Init. Repts., 107: College Station, TX (Ocean Drilling Program).

Kobayashi, K., and Isekaki, N., 1976. Magnetic anomalies in the Sea of Japan and the Shikoku Basin: possible tectonic implications. In Suton, G. H., et al. (Eds), The Geophysics of the Pacific Ocean Basin and its Margins, 19. Geophys. Mono., A.G.U., 235-251.

Lemoine, M., Tricart, P., and Boillot. G., 1987. Ultramafic and gabbroic ocean-floor of the Ligurian Tethys (Alps, Corsica, Apennines): in search of a genetic model. Geology, 5:622-625.

Lister, G. S., Etherridge, M. A., and Symonds, P.A., 1986. Detachment faulting and the evolution of passive continental margins. Geology $14: 246-250$.

MacKenzie, D. P., 1978. Some remarks on the development of sedimentary basins. Earth Planet. Sci. Lett., 40:25-32.

Malinverno, A., Cafiero, M., Ryan, W.B.F., and Cita, M,.B., 1981. Distribution of Messinian sediments and erosional surfaces beneath the Tyrrhenian Sea: geodynamic implications. Oceanol. Acta, 4: 489-496.

Malinverno, A., and Ryan, W.B.F., 1986. Extension in the Tyrrhenian Sea and shortening in the Apennines as result of arc migration driven by sinking of the lithosphere. Tectonics, 5:227-245.

Morelli, C., 1970. Physiography, gravity and magnetism of the Tyrrhenian Sea. Boll. Geofis. Teor. Appl., 12:275-309.

Moussat, E., 1983. Evolution de la Mer Tyrrhénienne centrale et orientale et de ses marges septentrionales en relation avec la néotectonique dans l'arc calabrais [Ph.D. dissert.]. Univ. Pierre et Marie Curie, Paris.

Moussat, E., Rehault, J. P., and Fabbri, A., 1986. Rifting et évolution tectonosédimentaire du Bassin Tyrrhénien au cours du Néogène et du Quaternaire. G. Geol., sp. issue 481-2:41-62.

Mutter, J. C., Talwani, M., and Stoffa P. L., 1982. Origin and seawarddipping reflector in oceanic crust off the Norvegian margin by "subaerial seafloor spreading." Geology, 10:353-357.

Rehault, J. P., Boillot, G., and Mauffret, A., 1985. The western Mediterranean Basin. In Stanley, D. J., Wezel, F. C. (Eds.), Geological evolution of the Mediterranean Basin. New York (Springer-Verlag), 101-129.

Rehault, J. P., Mascle, J., Fabbri, A., Moussat, E., and Thommeret, M., 1987. The Tyrrhenian Sea before Leg 107. In Kastens, K. A., Mascle, J., Auroux, C., et al., Proc. ODP, Init. Repts., 107: College Station, TX (Ocean Drilling Program).
Rehault, J. P., Moussat, E., and Fabbri, A., 1987. Structural evolution of the Tyrrhenian back-arc basin. Mar. Geol., 74:123-150.

Rehault, J. P., Moussat, E., Mascle, J., and Sartori, R., 1987. Geodynamic evolution of the Tyrrhenian Sea; new multi channel seismic reflexion data (ODP Leg 107 sites survey). Proc. VIIIth RCMNS Cong., Budapest, 70: Am. Inst. Geol. Publ. Hung., 281-286.

Rehault, J. P., Tisseau, C., Brunet, M. F., Louden, K. E., 1989. Deep crustal structure constraints on eastern Sardinian margin and central Tyrrhenian basin from thermal models, subsidence and heat flow analysis. XIV E.G.S. Meeting, Barcelona, 13-17 March, Ann. Geophys. Spec. Issue, 20-21.

Robin, C., Colantoni, P., Gennesseaux, M., and Rehault, J. P., 1987. Vavilov Seamount: a mildly alkaline quaternary volcano in the Tyrrhenian Basin. Mar. Geol., 78:125-136.

Ryan, W.B.F., 1973. Geodynamic implications of the Messinian crisis of salinity. In Drooger C. W. (Ed.), Messinian Events in the Mediterranean, Amsterdam (North-Holland), 26-38.

Ryan, W.B.F., Hsü, K. J., et al., 1973. Site 132. Init. Repts. DSDP, 13: Washington (U.S. Govt. Printing Office), 403-464.

Sartori, R., and Leg 107 Scientific Party, in press. ODP 107 Drilling in the Tyrrhenian Sea: a tentative comparison between the basin evolution and the surrounding chains deformations. Atti Accad. Naz. Lincei, Cl. Sci. Fis. Mat. Nat., Rend.

Sartori, R., Mascle, G., and du Chaffaut, A., 1987. A review of circumTyrrhenian regional geology. In Kastens, K. A., Mascle, J., Auroux, C., et al., Proc. ODP, Init. Repts., 107: College Station, TX (Ocean Drilling program), 37-63.

Selli, R., and Fabbri, A., 1971. Tyrrhenian: a Pliocene deep-sea. Atti Accad. Naz. Lincei., Cl. Sci. Fis. Mat. Nat., Rend., 50:580-592.

Selli, R., Lucchini, F., Rossi, P. L., Savelli, C., and del Monte, M., 1977. Dati geologici, petrochimici e radiometrici sui volcani centrotirrenici. G. Geol., 2:221-246.

Thomas, B., and Gennesseaux, M., 1986. A two stage rifting in the basins of Corsica-Sardinian straits. Mar. Geol., 72:225-239.

Trincardi, F., and Zitellini, N., 1987. The rifting of the Tyrrhenian Basin. Geo-Mar. Lett., 7:1-6.

Vink, G. E., 1982. Continental rifting ana the implications for plate tectonic reconstructions. J. Geophys. Res., 87:10677-10688.

Wernicke, B., 1981. Low-angle normal faults in the Basin and range Province: nappe tectonics in an extending orogen. Nature, 291:645648.

1985. Uniforme sense normal simple shear of the continental lithosphere. Can. J. Earth Sci., 22:108-125.

Date of initial receipt: 15 January 1988

Date of acceptance: 27 January 1989

Ms 107B-181 
LATE TORTONIAN - MESSINIAN

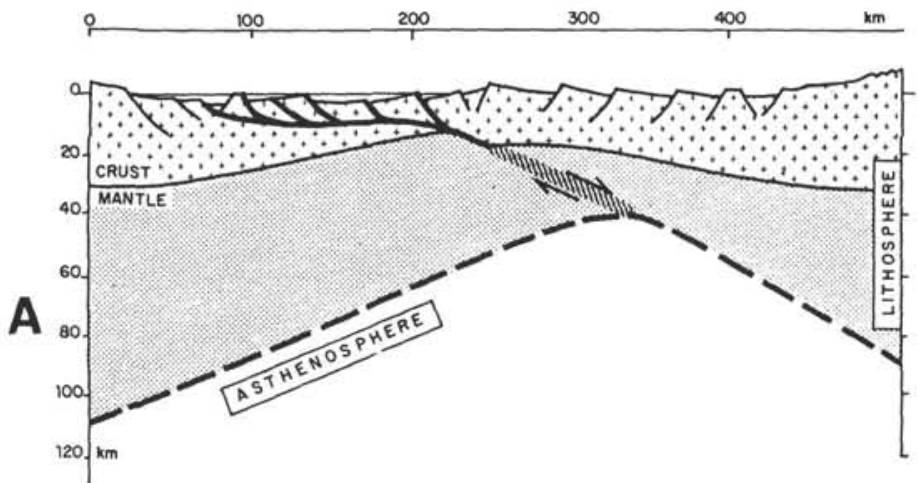

MESSINIAN - LOWER PLOCENE
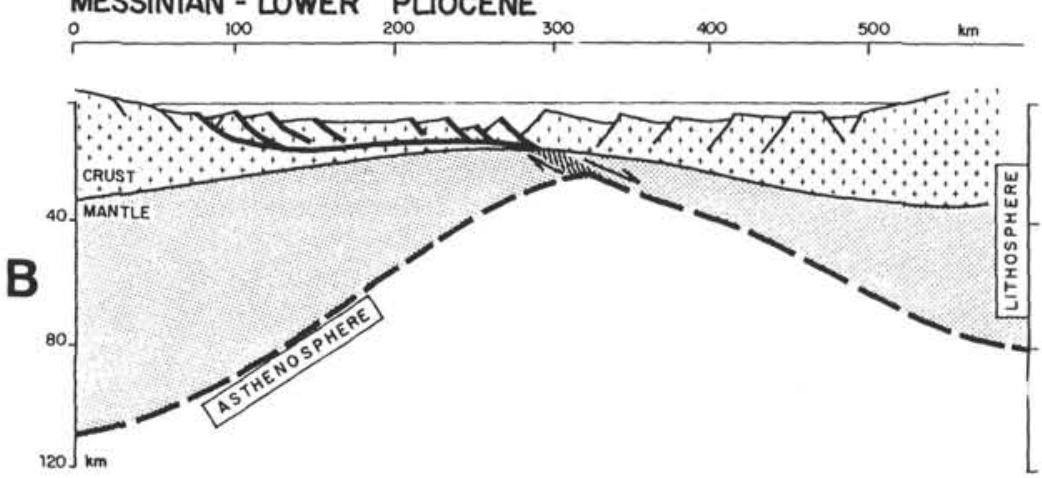

\section{PLIOCENE}

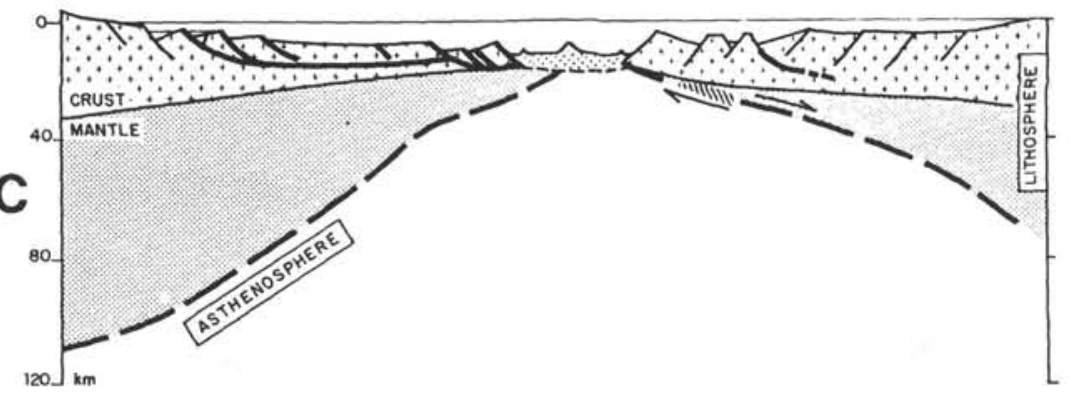

Figure 12. A tentative model of the evolution of the Tyrrhenian Sea; the model is based on a asymmetric margin evolution (detachment fault hypothesis). The cross section have been built for each stage taking into account the following:

1. Timing of rifting and nature of the basement as indicated by drilling,

2. Related distensive features and distribution of the oceanic crust,

3. Paleobathymetry as derived from seismic stratigraphy and drilled sedimentary columns,

4. Subsidence analysis as derived from sedimentary column, heat flow data, and related crustal and lithospheric thickness, and

5. The depth of the top of the asthenosphere as the $1333^{\circ} \mathrm{C}$ isotherm (base of the lithosphere) as proposed from thermal modeling in Rehault et al. (1989).

A. During upper Tortonian and Messinian times, the continental domain is progressively thinned thanks to crustal multidetachment fault systems cutting across the future Sardinian margin. Detachment faults may initiate on former Alpine suture/thrust zones running across the area. At this time, the future middle margin includes a series of already subsiding sedimentary basins while the future lower margin stands in a higher position. B. In late Messinian-lowermost Pliocene, the activity of the crustal fault system has progressively shifted toward the future lower margin; the area is subjected to a drastic lowering, maybe due to the reactivation of the so-called Central Fault system; by this time, the upper and middle margins are in a higher position than the intensively thinned lowermost margin. We may consider that extensional allochthonous blocks characterize most of this last area. C. During Pliocene times, oceanic crust is progressively emplaced within the Vavilov Basin due to the progressive drift of the eastern lithospheric domain and subsequent uprising of the asthenosphere. This may lead to emplacement of peridotites directly on the seafloor, as Vavilov Basin due to the progressive drift of the eastern lithospheric domain and subsequent uprising of the asthenosphere. This may lead to emplacement of peridotites directly on the seafloor, as
proposed by Lemoine et al. (1987). In the same time, the activity of the crustal fault system is progressively shifting along the eastern margin (maybe facilitated by the presence of Apenninic thrust zones). D. During uppermost Pliocene and Pleistocene, the Marsili basin is created similarly to the Vavilov basin. The fault activity may be now concentrated at the base of the Calabrian margin while a ribbon of continental crust is left between the oceanic Vavilov and Marsili sub-basins. The proposed sequence of events implies a clear asymmetry of the crustal structure of the Tyrrhenian domain. This has been probably facilitated by the presence of several crustal heterogeneities and initiated (or induced) by the southern rolling-back subduction and subsequent migration of the zone of maximum extension. 